Portland State University

PDXScholar

\title{
The Attack on Bourgeois Society: an Introduction to Cultural Despair in the Late Nineteenth and Twentieth Century European Thought, with Four Illustrative Studies from Traditions of the European Intellectual Milieu
}

Craig Evan Wollner

Portland State University

Follow this and additional works at: https://pdxscholar.library.pdx.edu/open_access_etds

Part of the European History Commons

Let us know how access to this document benefits you.

\section{Recommended Citation}

Wollner, Craig Evan, "The Attack on Bourgeois Society: an Introduction to Cultural Despair in the Late Nineteenth and Twentieth Century European Thought, with Four Illustrative Studies from Traditions of the European Intellectual Milieu" (1969). Dissertations and Theses. Paper 812.

https://doi.org/10.15760/etd.812

This Thesis is brought to you for free and open access. It has been accepted for inclusion in Dissertations and Theses by an authorized administrator of PDXScholar. Please contact us if we can make this document more accessible: pdxscholar@pdx.edu. 
Ali ASTRACT OF THE THESIS OF Craig Evan Volliner for the Master of Arts in History presented April $4,1969$.

Title: The Attack on Bourgeois Society: An Introduction to Cultural Despair in Late llineteenth and Twentieth Century European Thought with Four l11ustrative Studies from Traditions of the European Intellectual Milieu.

APPROVED BY MEHBERS OF THE THESIS COMMITTEE:

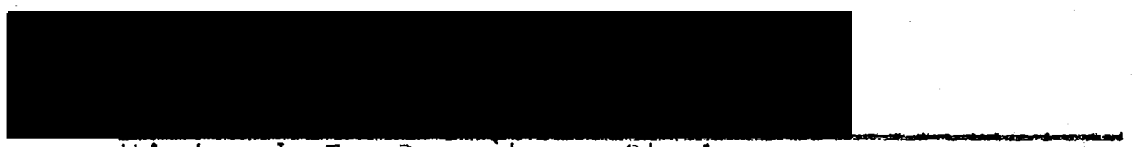

Michael F. Reardon, Chairman

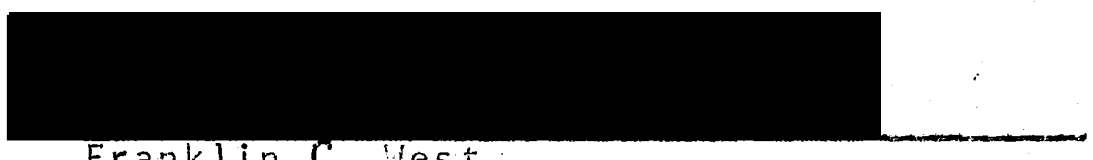

Franklin C. West

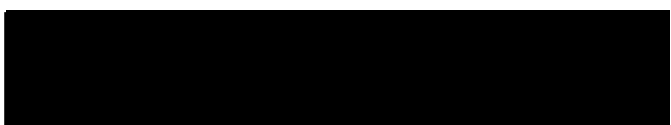

Ann Weike]

The rise of the middle class to power and influence in European culture and politics in the nineteenth century created the conditions of modern life which to many European intellectuals were distasteful and ominous. They viewed urbanization, commercialization, industrialization and the qualities of life that they engendered, such as anxiety, 
limitation of freedom, and pervasive mediocrity in cultural expression, as being inimical to the traditional and more reliable values of European civilization or, in some instances, as being incapable of providing the bases for a free and humane existence.

This study focuses on the attack on bourgeois society in Europe in the late nineteenth and twentieth centuries in an attempt to expand the definition of "cultural despair," a term to which it is related. Although others have discussed this general topic, cultural despair, the present study takes for its starting point the limited outlines offered in Fritz Stern's The Politics of Cultural Despair. This is undertaken for the dual purpose of exposing to historical scrutiny a background theme of European intellectual activity of the former and present centuries, and to help construct a historiographical tool with which the historian can seek to understand more readily the impact of the rise of the middle class and its consequences on the mind of Europe.

To reinforce the understanding of the topic of cultural despair, the essay offers four illustrations of cultural despair from traditions of the European intellectual milieu. These are the revolutionary, represented by Pierre-Joseph Proudtion and the critique of bourgeois economics; the literary, represented by $T$. S. Eliot and the critique of modern culture; the Catholic, represented by Emmanuel Mounier and his critique of bourgeois life; and the existentialist, represented by Jean-paul Sartre and the redefinition of freedom in modern 
life. Finally, this effort concludes with an attempt to synthesize the attitudes of these four men in their relation to the general subject. 
THE ATTACK OH BOURGEOIS SOCIETY:

AN INTRODUCTIOH TO CULTURAL DESPAIR

In

LATE HIHETEEHTH AND TUENTIETH CEMTURY

EUROPEAH THOUGHT

WITH

FOUR ILLUSTRATIVE STUOIES FROH

TRADITIONS OF THE EUROPEAN INTELLECTUAL

MILIEU

by

CRAIG EVAN WOLLNER

A thesis submitted in partial fulfillment of the

requirements for the degree of

MASTER OF ARTS

in

HISTORY

1

Portland State Univarsity 1969 
TO THE OFFICE OF GRADUATE STUDIES:

The members of the Committee approve the thesis of Craig E. Wollner presented Apri1 4, 1969.

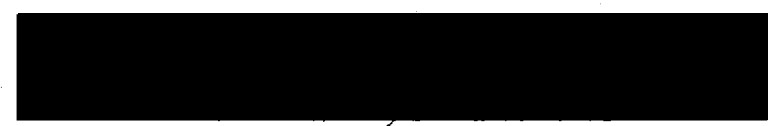

Michael F. Reard́on, Chairman

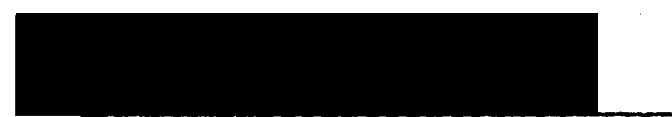

Ann Weike 1

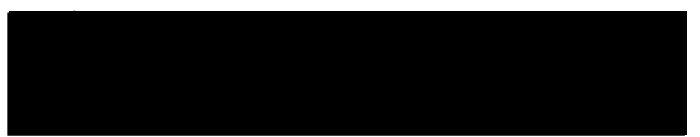

Franklin C. West

APPROVED:

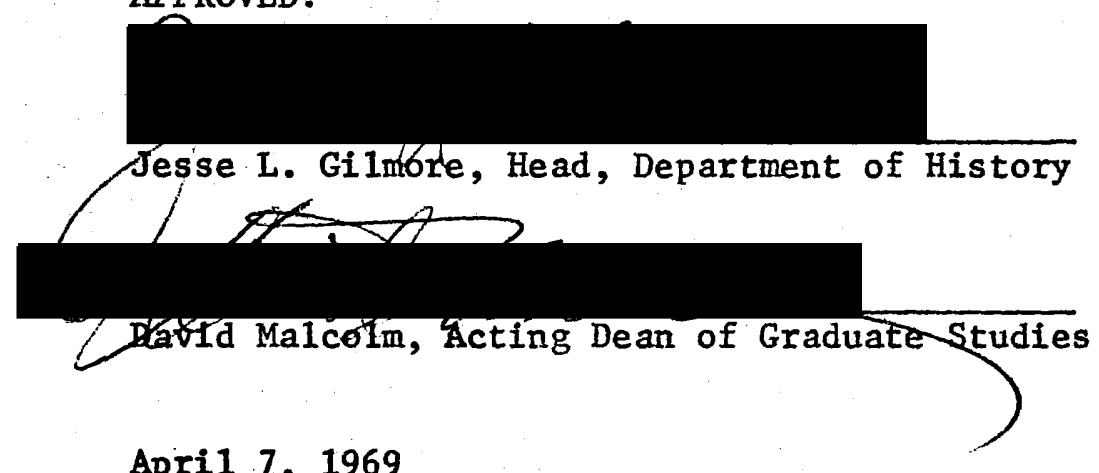

Apri1 7, 1969 
TABLE OF CONTENTS

Chapter

PART 1.

Page

1. INTRODUCTION TO THE PROBLEM. . . . . . . . . 2

11. THE STAGE IS SET. . ............. . . 10

111. THE INTERIOR OF ALIENATION. . . . . . . . 17

PART. 11

IV. PIERRE-JOSEPH PROUDHON: THE REVOLUTIONARY AND THE CRITIQUE OF BOURGEOIS ECONOMICS . . . 32

V. T. S. ELIOT: THE ARTIST AND THE CRITIQUE OF MODERN CULTURE. . . . . . . . . . . . . .

VI. EMMANUEL MOUNIER: THE "TRAGIC OPTIMISM" OF

THE MODERN CATHOLIC ............ 70

VII. JEAN-PAUL SARTRE: THE EXISTENTIALIST'S SEARCH FOR PERSONAL FREEDOH IN THE TWENTIETH CENTURY ................... 81

VIII. CONCLUSION: A MODERN THEME . . . . . . . . 93 BIBLIOGRAPHY . . . . . . . . . . . . . . . 101 
And here face downward in the sun

To feel how swift how secretly

The shadow of the night comes on ....

- Archibald Macleish,

"You, Andrew Marveli" 
PART 1. 


\section{CHAPTER 1}

\section{INTRODUCTION TO THE PROBLEM}

The historian's craft is delicate, his task arduous. In each piece of history he writes, he must do no less than lay bare the humanity which is at the core of all the memories that form the mosaic called civilization. Yet, unlike other scholars, the historian has few tools with which to measure the depth and breadth of emotion or the durability of fact. Mostly, he must rely on the same unscientific devices that a good novelist employs; that is to say, a highly developed imaginative quality, a commitment to truth, and above all, the ability to infuse his work with his own sense of humanity.

In a recent book review, an historian-critic noted that to do the most sensitive kind of historical writing, the scholar might now legitimately, perhaps necessarily, borrow methodology from the Freudian and Gestalt psychologists. 1 The framework of historiography, then, will become ontological as well as historical. ${ }^{2}$ If that

Peter Gay, "The Ascertained Past," New Republic, 159, (November 16, 1968), 22 .

2 In a brilliant essay, Hajo Holborn shows that Wilhelm Dilthey had reached similar conclusions nearly a century earlier. See Hajo Holborn, "Wilhelm Dilthey and the 
is true, to most thoroughly expose the temperament, whether of an individual, an age, or a culture, that produced the events he is recounting, the historian will be obliged to examine the condition of mind of that individual or age - its neuroses; if present, its psychoses. Now, as we know, the pure historian has railed at the very mention of Freud, but already Erick Erikson, among others, has successfully invoked his methods with restraint and success. ${ }^{3}$ At best, psychological history offers a refreshing and often telling approach. At worst, it is pompous, scientistic, and ahistorical, but the same criticisms can be made concerning any bad historical writing. 4

At any rate, the application of psychological criteria to the study of history offers an immense challenge to the traditional practice of the discipline. In one area of history, scholars have made notable but isolated attempts to integrate these criteria: European Intellectual History. Some of the best of these efforts have been devoted to the study of the rise of the Germanic ideology in the late nineteenth and early twentieth centuries, and related topics. The most

Critique of Historical Reason, "Journal of the History of ldeas, 11 , (January, 1950), 93-118.

3 In his biography of Martin Luther, Young Man Luther (New York, 1958).

${ }^{4}$ See for instance Sigmund Freud and William Bullitt, Woodrow Wilson (New York: Alfred A. Knopf, 1966), generally regarded by Wilson scholars as excessive in psychological interpretation. 
noteworthy of these works are Fritz Stern's The Politics of Cultural Despair and Hannah Arendt's The Origins of Totalitarianism. 5

In Stern's book there is a particularly engaging formulation of psychological, sociological, and historical material, the better to strike at the heart of the purely historical trend toward Nazism. Professor Stern labeled this formulation "cultural despair" and explained it as "a study in the pathology of cultural criticism." ${ }^{6}$ He attempted to answer this basic question: what were the psycho-social etiologies of the identifiable psychoses that caused a culture which could produce such humanistic spirits as Goethe, Schilling, Lessing, Beethoven, Bach, and in its last moments of sanity, Mann, to end by creating the most monstrous, abberative society ever conceived, let alone executed, by mankind?

The present paper seeks to expand Fritz Stern's concept of cultural despair and show how it can, by specifically. employing psychological categories, illuminate and inform the study of late nineteenth and early twentieth century historiography. 7

5Fritz Stern, The Politics of Cultural Despair (New York: Doubleday and Company, Inc., 1961); and Hannah Arendt, The origins of Totalitarianism (Cleveland: Horld Publishing Company, 1958).

${ }^{6}$ stern, Cultural Despair, 1.

7 it should be noted that, throughout, the writer has attempted to subordinate psychological criteria to historical. Thus, the reader will no doubt find a dearth of psychological nomenclature. 
To return to Stern, in The Politics of Cultural Despair, he decided that the most disgruntled and, therefore, most representative sector of German society, was the lower middle class. He tried to show that from this strata of German society emanated the pathology of cultural criticism that led to "a cultural crisis in modern Germany." 8 He also discerned that this cultural crisis engendered a "conservative! revolution"that, interestingly, he took to be a European as well as German phenomenon; but only in Germany became a decisive intellectual and political force. 9 Insofar as a movement of the terribie features and dimensions of Nazism appeared, nowhere else, that is true. But this paper contends that curtural despair was fundamental to the formation of the mentality of the age throughout Europe, that it cut across class lines, and was, however modest in comparison to its effects in Germany, a decisive intellectual and political force in all of western culture and, consequently, a valid theme for historical comment.

As a group, historians have always tended to run from any idea which shows signs of having universal application. Yet, to grasp its real import, we might do well to say a few words about the pervasiveness of the theme of cultural despair in the western intellectual tradition. 10 Briefly, it has

\footnotetext{
${ }^{8}$ Stern, Cultural Despair, 4.

9 lbid.. 15.
}

${ }^{10}$ The writer is aware of, but does not mention Vico, Spengler, and Toynbee, to name a few of the well known cyclical 
appeared in some form in nearly every period of recorded history: as simple dissatisfaction with existing conditions, concern for the course in which events seemed to be leading society, a thoroughgoing melancholy in cultural manifestations, or a grave fear, often expressed as a warning, for the future of the entire human race, as a result of its habitual misconduct.

of the last, no better example can be offered than one of the earliest, when, in Revelations, St. John the Divine writes of the apocalypse. 11 Much of the rest of the earliest articles of the Judaeo-Christian legacy is concerned with such terrifying visions, as, for instance, the literature of the Babylonian Captivity of the Jews, and that of the patristic church.12 Another example is the Middle Ages of western civilization, during which existence was harsh, engendered melancholy and pessimism to the point that these are leading characteristics of the age. In his classic study of the late medieval society. The Waning of the Middle Ages,

historians. They certainly fit in this context, but have been the subjects of many similar analyses. We should, also, take note of a similar cyclical approach to history in eastern thought, best represented in Chinese culture. For a full explanation see H.G. Creel, Chinese Thought (New York: Mentor Books, 1953).

11 New Testament, King James Version (Philadelphia: National Publishing Company, ig4i). See Revelation, 473-504.

12 For a full treatment of the apocalyptic vision in western thought, see Franklin L. Baumer, "The Twentieth Century Version of the Apocalypse," Journal of World History, 1. (January, 1954), 623-40. 
Johan Huizinga commented, "whether we read a chronicle, a poem, a sermon, a legal document even, the same impression of immense sadness is produced by them all."13

With this wider perspective, it should not be difficult to understand how this theme could significantly affect the mind of Europe in the period under discussion. Nor can we charge that historians have failed to detect its impact. What we can and will press here is that it has failed to receive the treatment it deserves. In The Origins of Totalitarianism, mentioned at the outset, Hannah Arendt demonstrated an acute awareness of the discrepancies between the social and political norms of the late nineteenth century and the images of them held by society in general.14 in her discussions of such peculiarly modern incidents as the Dreyfus Affair, the political emancipation of the bourgeoisie, the rise of modern racialism and anti-semitism, and the coalescence of the idea of the nation-state. Hannah Arendt showed that she understood that traditional historiography could not thoroughly plumb their dimensions and ramifications.

In his book, Consciousness and Society, H. Stuart Hughes rightly held that its contents filled a critical gap in our historical knowledge, the then unconstructed synthesis of the stories of those European thinkers who, had a "sense of the

13 Johan Huizinga, The Haning of the Middle Ages (Garden City. New York: Doubleday Anchor Books, 1954).

14 Arendt, Totalitarianism. 
demise of an old Society, coupled with an agonizing uncertainty as to what the forms of the new Society might prove to be.. . 115 The revealing subtitle of this book, "The Reconstruction of European Social Thought, 1890-1930," shows its author clearly understood the trend of the times, its continuation through the early years of this century, and his responsibilities in commenting on it.

K. W. Swart has written in The Sense of Decadence in Nineteenth Century France an assessment mainly of pessimism in French literature thróughout the century.16 At his best, Professor Swart links its literary manifestations with the harrowing course of French history; but he tends to view pessimism as a simple, direct, and finite response to the events he mentions. Perhaps a more perceptive examination of essentially the same material is Cesare Graña's Modernity and its Discontents, formerly entitled Bohemian and Bourgeoisie. 17 As the new title suggests, this work attempts to pinpoint the sources of the neuroses in French life of which literary pessimism was a symptom, much as Freud attempted, in civilization and its Discontents, to diagnose the modern condition.

A thoroughly rewarding study of mid-nineteenth century English intellectual currents is Walter Houghton's The Victorian

15H. Stuart Hughes, Consciousness and Society (New York: Vintage Books, 1958).

$16 k$. W. Swart, The Sense of Decadence (The Hague: Martinus Nijhoff, 1964).

17Cesare Graña, Modernity and its Discontents (New York: Harper Torchbooks, 1966). 
Erame of Mind. 18 In the complex rigors of society in this arresting era, the author discovered the origins of the categories of frustration and repression which are the hallmarks of its thought. And to magnify, as it were, some of the minds with which Houghton deals, an excellent source is Basil Willey, More Nineteenth Century Studies, a Group of Honest Doubters. 19

It will be seen from this brief synopsis that, in one form or another, the theme of concern for the culture has been noted to be a feature of modern European intellectual history. Moreover, unmentioned here are other studies which treat this theme in some brief fashion, or analyze deeply some incident of importance to it. ${ }^{20}$ What remains, then, is to characterize the age, expand Professor Stern's definition, and examine its parts.

18 Walter E. Houghton, The Victorian Frame of Mind (New Haven: Yale University Press, 1957).

19 Basil Willey, More Nineteenth Century Studies (New York: Harper Torchbooks, 1966).

${ }^{20}$ To name a few that come readily to mind: Nicholas Halasz, Captain.Dreyfus (New York: Grove Press, Inc., 1955), Henri de Lubac, S. J.. The Drama of Atheist Humanism (Cleveland: World Publishing Company, 1963), A. J. P. Taylor, Bismarck (New York: Vintage Books, 1967). 
CHAPTER 11

\section{THE STAGE IS SET}

It would be impossible, in the limited space available here, to reconstruct the events which brought the west to anxiety. Still, a gesture in that direction, for the sake of orientation, is desirable. A noted scholar once commented on the origins of the profound philosophy of a man whose intellectual biography he had written: he said it was not particularly astounding that a cross-eyed, plump, moody boy, who had grown up without ever having had a friend or been to a high school dance, should systematize anxiety, alienation, and individuality. 21 In the same sense, it is not difficult to understand how a culture which suffered the profound dislocations that afflicted the West during the late nineteenth and early twentieth centuries should doubt its ability to survive or the efficacy of doing so. The nineteenth century had begun in a cloud of uncertainty, a rash of confidence; there was opportunity and repression, innovation and reaction. The convulsions of 1789, 1791, 1792, and 1793 in France left.

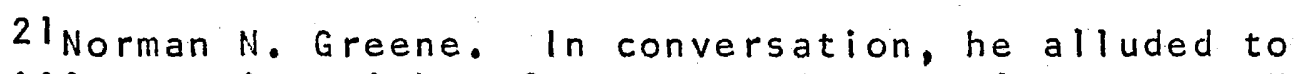
this illustration with reference to Jean-Paul Sartre. His book, Jean-Paul Sartre (Ann Arbor: University of Michigan Press, 1960), is a standard source for research in existentialism. 
not only that nation, but also all of its neighbors unsure of their futures. The brief interlude of the empire, which featured the spectacular career of Napoleon and his dream of redrawing the map of Europe, left an inevitable residue of insecurity and fear. 22 The white reaction which coalesced in 1815, at the instigation of Metternich, inaugurated, in the German states and the Hapsburg empire, an era of repression and police spy networks.

No amount of spies, however, could retard for very long the advance of the liberal trends in European politics. The Revolution of 1830 in France, the infectious fever of Paris' 1848 explosion, and the tragic episode of the Commune marked the inexorable advance of these trends. Of a similarly dramatic nature was the rise and unification of Germany under Bismarck, an episode characterized by a succession of ruthless wars which did, in fact, redraw the map of Europe. Yet another incident was the competition for empire among Britain, France, Germany, Russia and Japan: the European newspaper reader, in the later years of the century, learned the location and the tension of Fashoda and Tangiers, the folly and the peril of the Moroccan crises, the agonies of another world when the Boxer rebellion erupted in China and when, later, the Japanese and Russian armies clashed over a place called Manchuria.

22 There are many excellent studies of European history from 1789. Especially helpful are those by Gordon Craig and David Thomson. 
When at last the nineteenth century played itself out in its most harrowing experience, the Great War, no reasonably aware individual remained unmoved. But, as we know, the twentieth century was not to offer any respite. Reeled by the destruction wrought in the terrible battles of World War 1 , Europe was unable to immediately absorb the significance of the opening note of the new period. Still, the Russian Revolution dramatically altered the immediate outlook for everyone. Then, when the smoke of "the war to end all wars" had cleared, there remained in the consciousness of all Europe, a miasma of hate, fear, vengefulness, and uncertainty which conditioned all thinking and played no small role in the settlement at Versailles, the Siberian Intervention, the depression, and the failure of democratic forms in Germany, which culminated in the collapse of the Heimar Republic. Only during the brief honeymoon of Locarno in 1923, did Europe dare entertain thoughts of security. Finally, the triumph of totalitarianism in 1 taly and Germany complete the profile of a Europe in crisis.

Even such a compressed account as the foregoing captures the devastating anxiety which was the legacy of that foment. The drama of international politics is really only a backdrop for what must be considered the primary cause of the syndrome of cultural despair. Most people can somehow dilute, ameliorate, or simply ignore tensions that may intrude into their awareness secondhand, in the way political news often 
does. It is more difficult to avoid tensions caused by the alteration of one's own lifestyle. It was this last, the dramatic and abrupt change in socioeconomic forms which did touch each life, that is at the bottom of Europe's wounded psyche.

Fundamentally, this change consisted in the rise of the middle class and its assumption of preeminence in the European social, economic, and political system. Related, of course, to this problem, was the implementation of middle class norms; that is, the spread of the milieu from which the middle class operated: the urban, industrial, commercial society.

The-new order in society came abruptly. While it is true that much of Europe lingered on in pastoral bliss, in London, Paris, Berlin, Prague, and Vienna, the industrial society was breaking out early in the nineteenth century. By 1848, in France, railroads crisscrossed the land and more looms were in factories than homes. 23 Louis Phillppe, thanks to the upheaval of 1830 , had been for eighteen years the "citizen king," and Guizot, his chief minister, had already told the unenfranchised how to acquire the vote "enrichissez vous!"

In England, of coúrse, industrialization had proceeded apace since the very beginning of the century. Indeed, such thriving communities as Sheffield and Manchester mostly

23 priscilla Robertson, Revolutions of 1848 (New York: Harper Torchbooks, 1952), 13 . 
ored their existence to the new mode. Germany was another atter. The middle class in prussia, under the heavy heel of onc of the most backward regimes in Europe, failed to produce any significant alteration in its status, until, under Oismarck's policy of "Blut und Eisen," Germany awoke in 1870 from bumpkin rurality, to find itself fully embarked on a jarring and oppressive course of modernization. 24 of course, urbanization, industrialization, and commercialization were inextricably bound. As the factory system became the heart of European economic planning, urban growth became essential.25 It was the basis of the manpower pool which the factory system needed to survive. 26 Thus, layer upon layer of the unskilled and disoriented flowed into the cities from the countryside, creating distress, chaos, and congestion. 27 classical capitalism, regarded this as the material for a healthy labor market and refused to take any responsibility for the control of the influx, let alone for the well-being of those already working. 28 Manchester, for

24 see A. J. P. Taylor, Bismarck, for a lively study of

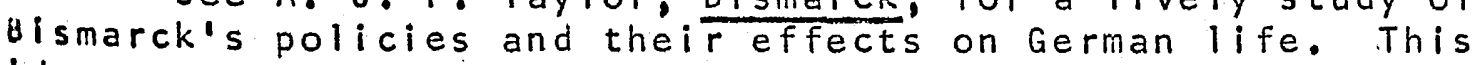
Idea may, essentially, however, be attributed to Mr. Franklin L. West, professor of German History, at Portland State College, Portland, Oregon. It was Mr. West's contention that cerman industrialization occurred more rapidly than anywhere else in Europe.

${ }^{25}$ Lewis Mumford, The City in History (New York, 1956), 455. $261 \mathrm{bid}$.

27 bid.

28 ibid.. 433 
instance, was in 1760, a town of 30,000 . In 1851, it was a cening city of $303,382.29$

Now capitalism dictated that the city be planned to increase land values. "The city," in the words of Lewis Mumford, "from the beginning of the nineteenth century on, was treated not as a public institution, but as a private commercial venture to be carved up in any fashion that might increase the turnover and further rise of land values."130 The character of the urban dweller's existence therefore evolved from disorganized hysteria to consistent oppressiveness. Perhaps the first sign of this gloominess was the virtual extinction of the more esthetic features of life - trees, flowers, parks, even pleasing buildings disappeared from the urban environment. 31 Rivers became sewers, expanses of 1 and which had once burst with greenery, suddenly were barren. Next, the overcrowded apartment house became a fixture as capitalists tried to profit from every rentable inch of space. London was marred by depressing row houses; the Berlin of Bismarck and the Paris of Napoleon 111 were characterized by the paradox of apartment house upon apartment house done in a uniform baroque. 32

29 lbid., 455.

30 lbid., 426 .

31 lbid.

32 lbid., 429. 
Even the neighborhood, once the center of urban social lifo was rent asunder as the traffic avenue imposed itself on wch city planning as occurred. In one bourgeois neighborhood in London, which Mumford discusses in his book, The City in ilistory, planners placed the shopping area along a corridor averive, causing the undernourished, ill-clothed inhabitants to valk great distances for recreation and groceries. 33 Given the facts of their general health, their lack of decent clothing, plus the burden of having to walk an average of two to three miles daily to get to work, it can be postulated with some confidence that here was a large number of individuals for whom 1 ife was aggressively unpleasant.

$1 \mathrm{t}^{-}$is no wonder that the reaction to these conditions should be the crudescence of neuroses and the growth of a mentality infinitely hostile to the qualities of the new age.

\section{3 lbid.}


CHAPTER || $\mid$

THE INTERIOR OF ALIENATION

The discrepancy between remembered existence and the forms of the new life in middle class society created in the European consciousness of the late nineteenth century the categories of frustration, hostility, and repression which Sigmund Freud was to discover and label neuroses. In Civilization and its Discontents he made the connection between the new life and the malaise of the mind which he had devoted his life to studying: in his view, neuroses were the price to be paid for the advance of civilization; "cultural freedom thus appears in the light of unfreedom, and cultural progress in the light of constraint. Culture is not thereby refuted: unfreedom and constraint are the price that must be paid.1134 The possibility of freedom which the liberal (i.e., bourgeois) tradition had promised early on, 35 never materialized. In fact, the supercession of liberal dynamics over old forms in society had actually created facets of the antithesis of the promised freedom: for free movement, restriction of

\footnotetext{
34 Herbert Marcuse, Eros and Civilization (Boston: Beacon Press, 1955), 18 .

35 see, for instance, the works of Mill, Bentham, Fourier, and st. Simon.
} 
movement, in the congested city; for equality, new class divisions (best discerned by Marx); for integration, alienation; for happiness, anxiety.

Because this failure was one of interior categories as well as physical ones, the reaction to it came in psychological as well as intellectual terms. That is, the aspects of the criticism of culture that emerged as cultural despair were formulated as much on the basis of emotional criteria as intellectual. The result was that the reactions that hardened into basic themes of cultural despair could be insidious and destructive. Some of these themes were middle class self-hate; nostalgia and the revivification of the conservative tradition; the sense of decadence; the revival of anti-semitism. These themes in turn engendered responses from men who, sensing evil in them, criticized a civilization in which such attitudes could appear. Yet most of these critics were themselves seduced by one or another of those themes. It will therefore be of some value to briefly discuss the attitudes that produced this web of ideas.

Middle class self-hate manifested itself usually in a very simple way. That is, most of the leading critics of middle class conventions were themselves men of the middle class. There was no way, for example, that either Marx or Engels could avoid the label, yet they were, to labor the obvious, easily the most relentless critics of the 
bourgeois.36 Similarly, Charles Peguy, Jean Juarès, Charles Maurras, Maurice Barres in France; Matthew Arnold, Bernard Shaw. T. S. Eliot in England; all these men had decidedly bourgeois origins, and yet made their careers by criticizing, in some way, bourgeois society.

The case of the young romantic moralist, Peguy, is instructive. In "Notre Jeunesse," written shortly after his socialist phase, Peguy discussed his desires for French society.

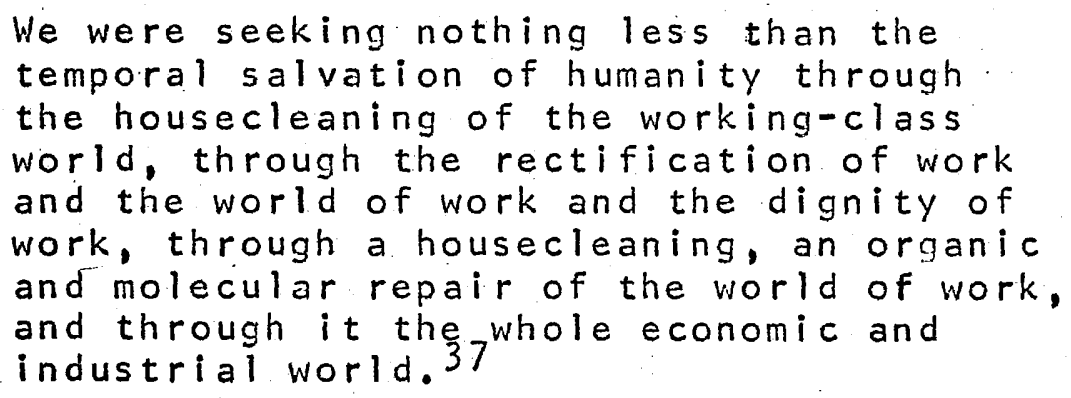

Peguy had put his faith, for a time, in socialism but it had not, to his mind, borne fruit. In the end, he and young Alain-Fournier, the sensitive novelist, set their store by the romantic mystique of France, the france of history, outside temporality and middle classness. 38 They were both rewarded for their fruit with death in the first weeks of the Great War; Peguy, a young lieutenant, leading a cavalry charge, sword in the air.

36 Isaiah Berlin, Karl Marx (New York: Oxford University Press, 1963).

37 Charles Peguy, "Notre Jeunesse," Posture of Europe, 1815-1940, Eugene C. Black, ed. (Homewood, I11inois: Dorsey Press. 1964), 379.

38 Hughes, Consciousness, 358 . 
Somewhat later, Jean-Paul Sartre, a bourgeois intellectual, displayed complete contempt for his background. As a young student during the '20's, Sartre andibis comrades were given to dressing as workers and mixing with proletaires in workingclass bars. 39

These men and others tortured by the inconsistencies of their society, thus often attempted to create an artificial ethos so that they might exist outside the stifling confines of the bourgeois society of which they were so much a part.

Here with a Loaf of Bread beneath the Bough, A Flask of Wine, a Book of Verse - and Thou Beside me singing in the Wilderness -

And Wilderness is Paradise now. 40

In those famous lines, Englishmen found something about which to daydream in the $1860^{\prime} \mathrm{s}$ and $70^{\prime} \mathrm{s}$. The pace of modern life gave men no respite. Its features were usually only repeated and analyzed in literature. Here, in Edward Fitzgerald's translation of the Rubaiyat, were the ingredients of the past which were so far removed from reality and yet so very attractive. The pastoral, the isolated, the primitive These were the very antitheses of the conditions of modern life, and were, apparently, what made the fitzgerald translation such a huge success. 41 Nor was this a unique incident.

39 Jean-Paul Sartre, Search For a Method (New York, 1963), 18. ${ }^{40}$ Carl J. Weber, ed., Fitzgerald's Rubaiyat (Waterville, Maine: Colby College Press, 1959), 47.

41 lbid. See the introduction to this edition, for a summary of the book's interesting publishing history. 
Throughout Europe, men turned to the past to support them in their journey through the present. No incident is more familiar to the cultural historian than the popularity of Grimm's collection of fairy stories in Germany. As one critic tells it,

it was appropriate that, when all old values and beliefs were being discredited by ... the new confident bourgeois civilization, some men should go back, surreptitiously, to the past, for help in surviving in a time when everything spiritual had disappeared but selfconfidence. The brothers Grimm were right in

Thus did nostalgia become part of the European reaction to modern life. Strangely, the nostalgic impetus had two somewhat diverse effects. The first was that only a few literary men, contrary to what might be expected, created nostalgic visions of the past. The Wasteland of T. S. Eliot is perhaps the best expression of this. In it, Eliot compared the past to the present, opting for a return to the values of the past. 43 Mainly, however, the artistic vision was of a decadent society, a system whose ethic and aesthetic had been irretrievably corrupted. Eliot's contemporary, Ezra Pound, raged about "a botched civilization; an old bitch gone in the teeth, 144 and this enunciated clearly the point of view of many members of the artistic community.

42 Ralph Harper, Nostalgia (Cleveland: Western Reserve University Press, 1966$), 13$.

${ }^{43}$ T. S. Eliot, "The Wasteland."

44"Hugh Selwyn Mauberly" in Ezra Pound, Personae; The Collected Poems of Ezra Pound (Norfolk, Conn: New Directions, 
As the theme of decay gained currency in the world of literature, its facets were easily identifiable. One genre was the celebration of decadence for its own sake. The best known practicioners were Charles Baudelaire, Joris Karl Huysmans, André Gide in France, and Oscar Wilde in England. Baudelaire wrote of the baseness and depravity of modern life from what might facetiously, but truly, be called exhaustive research into the matter. As his translator, Jacques Leclereq has put it, "he was already syphilitic and addicted to drugs at an age when his fellows were dreaming of chamber maids. . . He died paralytic, speechless and insane." 45 Yet this man, who lived his life past the outer limits of excess, was an admirer of the doctrines of Joseph de Maistre, the archconservative of the early nineteenth century, who had called for a reassertion of the very institutions which Baudelaire's conduct mocked - the church and the family. 46 Baudelaire had nothing but contempt for modern society and the belief in progress and he often railed against it. 47 Yet his poetry evoked not a longing for the old order - he was a man who had long ago passed that stage - but was firmly grounded in an aesthetic distilled from the corruption in which the modern world had immersed itself and its inhabitants. For Baudelaire,

\section{Charles Baudelaire, Flowers of Evil (New York: Peter} Pauper Press, 1958), 1. Decadence and degeneracy has been, in France at any rate, a viable artistic mode down to the present day; cf. the work of Jean Genet, whom Sartre has called St. Genet. 46 Swart, Sense of Decadence, 113. 47 lbid. 
the old values had long since been buried by the interminable grossness of the new age. It was as useless to turn back as to try to move forward. The only salvation, the only respite, was in a complete acceptance of the sin of the new world.

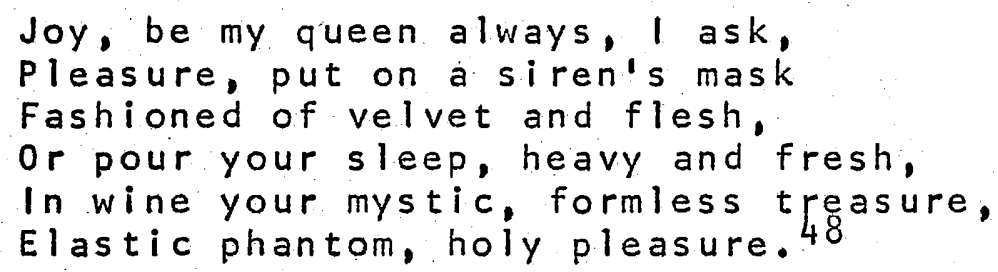

Baudelaire had an enormous oedipus complex; Wilde and Gide were raging homosexuals. For Gide, the moral standards of his times were irrelevant. In The Immoralist, his

protagonist had been dealt a severe blow by middle class life and conventions. Escaping to a Tunisian beach, he suspended adherence to those conventions, and gave himself over to languor. Matter-of-factly, he accepted, even enjoyed his own moral decay. In his final remarks, Michel, the protagonist, mused about his sexual predilictions, as they concerned a beautiful young prostitute and her brother. "Every time 1 meet her [the prostitute], she laughs and declares that 1 prefer the boy to her. She makes out that it is he who keeps me here. Perhaps she is not altogether wrong. . . 149

Often, the very existence of these men was an affront to proper society. A rather well-known poem on the demise of that all-time reveler and gadfly. Oscar Wilde, is an example.

$$
\begin{aligned}
& \text { 48 Baudelaire, Flowers, "Envoi," } 51 . \\
& \text { 49André Gide, The Immoralist (New York: Vintage Books, }
\end{aligned}
$$
$1958), 147$. 
With cynicism uppermost, its author parodied what was in the minds of most upright citizens as the word went out:

When oscar came to join his God, Not earth to earth, but sod to sod, It was for sinners such as this

Hell was created bottomless. 50

If decadence was a way of life for some artists, for others it was an indictment of crucial institutions. For example, a wave of novels wholly or partly concerned with the corruption of religious ideals and the crisis of the modern religious conscience appeared. These included The Damnation of Theron Ware, Martin Du Gard's Jean Barois, and Joyce's Portrait of the Artist as a Young Man. In each, the protagonist struggled to square secular life with religious faith. Sometimes, like Joyce's hero, Stephen Daedelus, he failed. Trenchantly, Stephen declared his stand on Catholicism, to which he was born, and Protestantism, to which, his friend Cranly had thought he might defect.

I said that I had lost faith, Stephen answered, but not that 1 had lost self respect. What kind of liberation would that be to forsake an absurdity which is logical and coherent and to embrace one which is illogical and incoherent? 51

As Swart notes, for the French and English, literary decadence was as much an "esthetic posturing" as a serious concern for the social decay of civilization. 52 certainly

50 Attributed to Algernon Charles Swinburne.

51 James Joyce, Portrait of the Artist as a Young Man (New York: Viking Books, 1958).

52 Swart, Sense of Decadence, 249. 
their seriousness of purpose in this respect did not measure up to that of the Germans and the Russians - Schopenhauer and Nietzsche among the Germans, Tolstoy and Dostoevsky in Russia, to name a few, but it seems safe to say that insofar as the nostalgic longing had created an awareness of the unsatisfactory qualities of modern life in such men as Baudelaire, Gide; and Wilde, then the decadent response was a serious part of the syndrome of cultural despair. 53

Nostalgic longing was a factor also in the revivification of political conservatism. The term "revivification" should not be misconstrued. Conservatism was never really moribund. But the discrepancy between remembered or imagined past and the reality that was projected by what appeared to be the excesses of the new barbarism, calalyzed in some Europeans a longing for the old order. 54 Conservatives, therefore, had to devise new schemes to surmount modernity and this was the substance of the revivification: whereas prior to the rise of bourgeois society, the conservative had to provide rationale for the existing order, its arrival obliged him to attempt to

53 Friedrich Nietzsche, Joyful Wisdom (New York: Frederick Ungar Publishing Company, 1954) and Fyodor Dostoyevsky, The Brothers Karamazov (New York: Dell Publishing Company, Tnc., (956); see the famous "Grand Inquisitor" section. A good discussion of both is available in the above mentioned Drama of Atheist Humanism.

${ }^{54}$ As a matter of course, the remembered or imagined past bore no relation to the reality of the past. The volk, for instance was an artificial creation of the German ultraright, its antecedents being, really, diverse and eclectic traditions. 
destroy it. This shift in emphasis engendered a lull in political conservatism which lasted from Hegel roughly to Bismarck.

In political conservatism especially, did cultural despair cut across class lines, for it was in the realm of polemic that those whose positions had been destroyed or were most seriously threatened by modern institutions, could best attack the bourgeoisie. Moreover, in the nation-state of the late nineteenth century and in the period between the wars (when, H. Stuart Hughes observed, a curious generation, in France particularly, more susceptible to conservatism than its fathers appeared55) men of all classes were concerned with two phenomena which afflicted them to the degree that they developed into full-fledged paranoias. The first fear was of the urban mob and its alliance with capital or the power elite. This fear was, of course, realized in Germany in the gangs of the late Weimar and early Nazi period.56 Here were urban ciphers, usually disgruntled, disoriented veterans, technologically unemployed, who were an awesome instrument of terror and, ultimately, state policy. If, however, the unruly mobs did not elicit a phobic reaction from many intellectuals in Germany, it was because they, as well as most other respectable Germans, were locked into the same

\section{Hughes, Consciousness, 341.}

${ }^{56}$ see Arendt, Totalitarianism. Allan Bullock, Hitler, a Study in Tyranny (New York: Bantam Books, 1961). Marshall
Dill, Jr., Germany, a Modern History (Ann Arbor: University of Michigan Press, 1961), to name a few. 
rars and frustrations which made the mob so malleable. On the other hand, more than one historian has discovered that incidents of mob violence have usually been more than matched by the excesses of the white reaction.57 In any case, this fear was in part responsible for the attack on bourgeois democracy which was a persistent theme in the works of conservatives like Maurras and Barres.

The second fear was one which became important after World War 1. It was best expressed by the Spanish social commentator, José Ortega y Gasset. He and others felt that industrialization was so pervasive a force in continental life, that it would lead to the total submersion of traditional ethical, esthetic, and intellectual principles, by the preoccupations of industrial society, that is, science, technology, and the exigencies of market economics. The awaited metamorphosis was rather universally thought of by intellectuals, depending on their point of view, as the Americanization or Sovietization of European 1 ife.58 To Ortega it meant "the accession of the masses to complete social power."59 It meant "the barbarism of specialization."60

57 See George Rude, Revolutionary Europe (Cleveland: Meridian Books, 1964), and Jeffry Kaplow, ed. New Perspectives in the French Revolution (New York: John Wiley and Sons, inc., T965T two excellent studies on this dimension.

58 From class notes from Dr. M. F. Reardon, History Department, Portland State College, Portland, Oregon.

59 Jose Ortega y Gasset, The Revolt of the Masses (New York: W. W. Norton and Company, 1957), 11.

${ }^{60}$ See Ch. $12,107-114$. 
it meant the obliteration of all class lines, intellectual, social, political, as men became bound in one commonality Sy a single trait - mediocrity. 61

In the late nineteenth and early twentieth centuries antisemitism was a synthesis of all the neuroses which formed the syndrome of cultural despair. As Hannah Arendt has shown, in the Jew of the period was embodied the ideals for which bourgeois society stood. 62 The Jew was urban and utilitarian, tending to enter the bourgeois service professions such as law, medicine, science, journalism, and commerce. The Jew was the creation of the bourgeois state, in that he was emancipated by law under its auspices during the nineteenth contury, so that he owed allegiance to it; in not a few Instances he helped to perpetuate the state by working directly for its well-being (as Dreyfus, an army officer) or doing its cxpress bidding (as Bleichroeder, Bismarck's most important war financier.) Finally, inasmuch as he was the creation of the bourgeois state, the Jew was two paradoxical things which were at the heart of the middle class ethos; he was declassé (his origins, by the terms of his emancipation, no longer mattered), and he was thoroughly middle class, since he was usually in a bourgeois profession, on the one hand, and on the other was incapable of social advancement, because, in spite of everything, he was still a jew.

61 see Ch. 2, 19-27.

${ }^{62}$ Areridt, Totalitarianism. See Chs. $1-4$. 
In the backward lands of eastern Europe, anti-semitism remained a basically medieval superstition until well into the present century. Peasants could be whipped to a murderous frenzy by an agitator's tales of Jewish ritual murders and other blood rites, which had no basis in fact. It was only natural. In most of Poland and Russia, the rural ways of life persisted, and Jews remained separated, cut-off from society. There were an enigmatic, unknown factor, much as they had been for centuries before. In the western industrial sections of Europe, however, the Jew was the victim of the new antisemitism and became the hated archsymbol of industrial society. 63

Earlier in this study, it was stated that Hannah Arendt had correctly concluded that one could not, in purely historical terms, comprehend the development of European social, political and intellectual history in the period we have discussed. This, she said, was true because in that time many men were led by the exigencies of modern life to make, for the first time, a connection between private anguish and the large and otherwise impersonal events which filled the world, creating a huge and pregnant context.64 Nostalgic longing, decadence,

631 should be noted that most such anti-semitism originated with conservative critics. Radical critics of society did not tend to be anti-semitic because, usually, they were egalitarian, and, usually, they were jews. Arendt, however, includes a section on leftist anti-semitism, 42-50.

64 she was thinking specifically of the French racist, Gobineau; Arendt, Totalitarianism, 175. 
anti-semitism, and thus, cultural despair were created from this context. Freud and his colleagues saw them as evidence that life had come to a pass at which the state of culture and society were constants in the diagnosis of the health of the psyche. Inner experience had now been given historical significance or, to use Hannah Arendt's phrase, "one's own self had become the battlefield of history. 165

In the four studies that follow, these considerations will be seen to form the context from which the studies proceed. Each study represents an effort to show the pervasiveness of cultural despair in four vital traditions of European thought of the nineteenth and twentieth centuries: the revolutionary, the literary, the Christian, and the existentialist. These are four traditions of many, but they, particularly, have been hospitable to the kinds of men who have given substance to the phenomenon of cultural despair.

65 ibid. 
PART II. 
CHAPTER IV

PIERRE-JOSEPH PROUDHON: THE REVOLUTIONARY AND THE CRITIQUE OF BOURGEOIS ECONOMICS

At the feet of the Jura mountains, runs the River Doubs. At a certain place, there is a u-shaped curve: the old city of Besançon is cradled there. Besançon gave France Charles Fourier. Just Muiron, and Hippolyte Raymond, and on February 15 , 1809, Pierre-Joseph Proudhon was born there, in Battant, a suburb populated by craftsmen and petit bourgeois land owners.66 He was the son of peasants who were gradually being absorbed into the urban middle class; his father had been before Pierre-Joseph's birth, a barrel maker, would be later an innkeeper and brewer.

The Proudhon family had split into "right" and "left" factions, as its members settled into middle class society. The rightist proudhons were made up of professional people, François-Victor was a professor of law at Dijon, JeanBaptiste, a member of the Directory for the Doubs. The leftist branch, on the other hand, consisted of peasants,

66see Geroge Woodcock, Pierre-Joseph Proudhon, a Biography (London: Routledge \& K. PauT, 1956), and Henri de Lubac, The Un-Marxian Socialist; a Study of Proudhon (New York: Ward and sheed, 1948), for comprehensive biographical treatment. The treatment of Proudhon's life presented above is based, substantially, on material from these two sources. 
craftsmen, urban petit bourgeois. This group tended toward rebellion and obstinacy. Melchior, Pierre-Joseph's cousin, had, in 1789, abandoned the cloth to lead the Revolution in Besançon, and was imprisoned during the Terror. He later. went so far as to become a Freemason. The proudhons of the left seem uniformly to have suffered from a spectacular lack of financial success, the result, in family legend, of a Papal curse. Pierre-Joseph's father was a good example. Due to a second sense for the wrong decision, Claude-François always kept his family in financial peril. The elder Proudhon's business canons were honesty, integrity, and a fair price, and he adhered to them rigidly. Admirable though these standards were, however, they seem only to have contributed to his commercial ineptitude.

Pierre-Joseph's mother was Catherine Simonin, a simple peasant woman, who nonetheless educated him in his earliest childhood. Proudhon admired his mother, and said, throughout his life, that he owed all he was to her. She, like her husband, came from a radical background. Her father, known as "Tournesi," had been something of a local agitator, decrying rentiers, tax farmers, and the crown. Tournesi died after slipping on an icy road in the winter. He had been on his way to spread revolt among his neighbors. It was 1789 .

The political and economic dislocation visited upon France as a result of the Napoleonic wars forced Proudhon's family into a brief but arduous sojourn on Tournesi's farm 
near Burgille. His father's simple honesty in business atters had reduced the family to these desperate straits. on the farm, simple honesty produced barely enough for the family to subsist on.

In 1820, Pierre-Joseph won a scholarship which allowed him to attend the Royal College at Besançon. Not so much brilliant as dogged, he won the class prize every year, struggling at his lessons without books. Early on, he became jaded by and unhappy with his parochial education. In 1825, lduring the period of the Bourbon Restoration, then al ready eleven years old, a mission was preached at Besançon, the pietistic exhortations of which thoroughly repulsed the sixteen-year-old Proudhon. That was a turning point, it seems. He never really returned to the church, if indeed, he had ever really committed himself to it.67

On prize-giving day, 1826, Pierre-Joseph came home loaded with honors to discover the farm had been lost in a lawsuit. He managed one more year in college and, then, in the autumn of 1827 started work as a printer and proofreader, in the employ of the firm of Gauthier. From this point, to all intents and purposes, he was launched on his career.

Hegel observed that great events and personages repeat themselves in history. In discussing. France during the crucial years of the mid-nineteenth century, Marx refined the idea:

67 proudhon abandoned the church, but assuredly kept his faith, after his fashion. Lubac's Un-Marxian Socialist deals with this problem. 
they occur, he said, "the first time as tragedy, the second time as farce.1168 And, in spite of the substantial ridicule he had meant to heap on his subject, he was mainly correct. In 1830, the last remnant of the ancien régime had given way to what was to become a new tyranny, the July monarchy of Louis Phillppe, the "citizen-king," and his chief minister, Guizot. In 1831, there were never more than 250,000 qualified voters in all of France, out of a population of $9,000,000$ adult males; only those who paid a direct tax of 200 francs or more could vote.69 "Get rich; then you can vote," said Guizot crassly, as the clamor for election reform grew. This new tyranny was, then, a caricature of the old; capital counted instead of title; shopkeepers now ruled, in Louis Blane's words, a nation of warriors. In another July, this of 1848, the poet Lamartine promised that the new tyranny would fall, not in its own blood as had the old in 1789, but in its own trap; promised that the revolution of liberty would become the revolution of contempt.70 Ultimately, when the revolution foundered, it was rescued by a Bonaparte, not a great hero, as had been the fortune of 1800 , but, in Bismarck!s words, "a great, unrecognized incapacity." This Bonaparte. was Louis, the supreme bourgeois romantic for the supreme

68 Karl Marx, The Eighteenth Brumaire of Louis Bonaparte (New York: International Publishers, 1963), 15.

69 priscilla Robertson, Revolutions of 1848. (New York: Harper Torchbooks, 1960), i5.

701bid., 11. Miss Robertson's source is Daniel stern, Histoiredela revolution de $1848,1,2$ nd ed. (Paris), 21 . 
classicist, the nephew for the uncle.

Actually, as Priscilla Robertson has pointed out, prior to 1848, France appeared to be the home of liberty, compared to the rest of Europe.71 Freedom of the press was taken for granted, criticism of the regime was frequent and often scurrilous, trial by jury was well established, and government was entirely by law.72 Among the working classes, the most obvious concern was for electoral reform, and this they pressed vehemently. The Reform Bill of 1832 had given wider enfranchisement in England, and the voteless of. France saw no reason to be denied, simply because they lacked property.

Proudhon, stimulated by the tone of the times, was a well-known figure of this era. in France, having already established himself with What is Property? and other minor pieces. After the 18 th Brumaire, he was even occasionally invited to dine with the Emperor himself. The Baron D'Ambres, an intimate of Napoleon 111 , noted in his memoirs that Proudhon was always brought in to spice the evening up - Napoleon took a "psychological interest in his comedy."73 For these occasions, he always appeared in a clean collar, while, the Baron noted, for other less important social events, he usually affected a pea jacket, a broad brimmed hat, "coarse

71 lbid., 13.

72 lbid.

73 Baron D'Ambres (A. R. Allison ed, and trans.), Intimate Memoirs of Napoleon 111, 1 (Boston: Little Brown \& Company, 1912).96. 
cloth," and a walking stick, which he leaned on after the fashion of Balzac.74

Though his social criticism was often savage, Proudhon was neither so radical as he liked to think nor as his enemies feared. He was firmly rooted in the traditions of French radical political and economic theory. 75 The spirit which was in him, had also been inherited, in his own time, by Fourier, St. Simon, Comte, and Blanc. Like Fourier, he distrusted centralized power in any form. 76 Like Blanc, he distrusted laissez faire, which he thought endangered the social order and delayed economic progress. Like St. Simon, he put his faith in the idea of associations of men living together in harmony and economic and social justice.

In his best known work, What is Property? he went to what he felt was the root of the inequities of modern society, and in attacking private property he was essentially no different from his predecessors. Only more clever. "property."

74 bid.

$751 t$ is instructive to note that a modern critic of the French left, best known for his cynical appraisals, has charged that "the French left. . combines complete selfsufficiency in all theoretical matters with an infinite ignorance of economics... The result is thinking in terms of slogans, and the use of such simple and absolute categories as 'masters and slaves,' 'rich and poor,' 'oppressors and oppressed." Herbert Luethy, France Against Herself (New York: Meridian Books, 1957), 441. This allegation has also been made with reference to the entire French radical tradition, including Proudhon.

76 Frank Manuel reports that, while a young printer in Lyons, Proudhon set up in type Fourier's Theorie: des quatre mouvements et des destinees aenerales. In the prophets of Paris (New York: Harper Torchbooks, 1962), 199. 
sid proudhon, in a phrase which became a radical shibboleth, "is robbery." Here, he was, in essence, attacking the political itandards of the Second Republic. The concept of property sssigned to him who possessed it the legal right to decide the future of another who did not. To Proudhon, this was an abridgement of inalienable political rights, affirmed in 1789. Enfranchisement by property thus stole a man's natural rights. Here Proudhon was squarely in line with Rousseau.77 Being in line with Rousseau is no great accomplishment since most western social thinkers before and since could probably claim the same distinction, but in this instance, Rousseau derived from the more solid ground of the natural law tradition of European thought, which thus links proudhon to it also.78 If 1789 had affirmed the rights of man, for Proudhon it also established three categories of middle class behavior which were antitheses of the fairest methods of social and economic behavior. These were,

(-1) Sovereignty of the human will; in short, despotism. (2) Inequality of wealth and rank.

(3) Property - above JUSTICE, always invoked as the guardian angels of sovereigns, nobles, and

77 See A. Noland, "Proudhon and Rousseau," Journal of the History of Ideas, 28, (January, 1967), 33-54 for a fulter treatment of this connection.

78 It would not be difficult to insert, at this point, a quotation from The Social Contract of Rousseau (Chicago: Henry Regnery Company, 1954), but it might be intellectually dishonest. Where any supportive statement one might find in this book is not contradicted earlier or later on, it is probably vague and really inconclusive. See, however, pp. 27-32 of the social Contract, Noland's above mentioned article, and Frede rick Coppleston's standard survey A History of Philosophy, VI, (Garden City, New York: Image Books, 1964), 75-121, for a a brief synopsis of Rousseau's ideas. 
proprietors; JUSTICE, the general, primitive, categorical law of all society. 79

Proudhon capitalized all the letters of justice because he believed it to be the ultimate test of the validity of all human institutions and ideas. In What is Property? he asked, "is the authority of man over man just?"100 "1s political and civil inequality just?" 81 "Is property just?" 82 In a letter to the perennial revolutionary. August Blanqui, he answered himself: "men equal in the dignity of their persons and equal before the law, should be equal in their conditions."183 It is clear that, to proudhon, the only justice lies in total equality, and that property is the greatest single obstacle to justice and equality. Justice, moreover, is a "simple abstraction, an idea, a connection [un rapport] considered concurrent with the general laws of nature and the spirit."184 Equality is also of the natural order, it must be, otherwise, "of what significance is Justice?" 85

79 pierre-Joseph Proudhon, What is Propertyl (New York: H. Fertig, 1966), 37. It could reasonably be suggested that the above quotation places. Proudhon squarely against Rousseau; such are the exigencies of Rousseau's thought. See the Social Contract, especially those chapters on sovereignty, pp. $\overline{140-155}$.

80 lbid., 38.

81 bid.

82 Ibid., 39.

83 lbid.; 292 .

84 pierre-Joseph Proudtion, De la justice dans la revolution et dans l'egalite, 1, (Brussels: Office of Publicity, 1860), 34 . 85 ibid. 
Here Proudhon turns to anarchism. Once property is abolished, equality in justice will replace the artificial social, political, and economic divisions of middle class society that property had created. All traditional forms are suspended, but at the core remains the old utopian theme of association, not to say a definite flavoring of Enlightenment optimism and reliance on reason.

Nobody is king; we are, whether we will or no, associated. Every question of domestic politics must be decided by departmental statistics; every question of foreign politics is an affair of international statistics... Every citizen is a legislator. But, as the opinion of no one is of any value until its truth has been proven, no one can substitute his will for reason nobody is king.

It was noted at the outset. that early in life, Proudhon had strayed from the church. What we neglected to say was that like Kierkegaard, 87 he clung tenaciously to his own special faith. For God, not man, was the ultimate guarantor of reason, of the associative tendency in man, of equality and justice. As in the seventeenth century philosophers (such as Vico,) God (or Providence) unified history and existence. In système des contradictions (philosophie de la misère) Proudhon attacked Christendom - the church, its faithful, theologians, theology - which had become the preserve of the bourgeosie, but had only the warmest praise for God. God was not "the sovereign arbiter of the universe,

86 Proudhon, Property?, 278 .

87 of whom Proudhon never had the slightest knowledge. 
ac King infallible and irresponsible to his creatures, of a art that can be understood by man;" God was, instead, "ilc eternal being, immutable, pervasive, infinitely wise, infinitely free. 1188

Once the old legal norms of property and state were abolished, Proudhon saw that certain devices would have to be created to start and perpetuate the new system; God, reason, and association notwithstanding. He therefore created the Idea of a huge national bank, a "people's bank," which would, ironically, be funded initially by property taxes and a progressive tax on the salaries of government officials. 89 Since interest has a tendency to fall, the competition of the people's bank, lending money gratis, would drive it to its true normal rate - zero. Rents and profits would then inevitably cease; without interest and profit, everyone would be associated on terms of equality. The only remaining norm of the old society would be the contract, in which men would be bound to each other by the sacred bonds of corresponding rights and obligations.

Proudhon, in his eagerness to destroy bourgeois society, could not contrive to leave any existing institution alone. He even found it necessary to criticize marriage. In one of his more obscure, but no less controversial questions, he

$$
{ }^{88} \text { pierre-Joseph Proudhon, systeme des contradictions, } 1 \text {, }
$$
(Paris: Ernest Flammarion, 1897 ), 366.

${ }^{89}$ see Property? ch. 5 and Systeme, $1, \mathrm{ch} .10$. 
asked, "what is marriage?"90 He answered himself with another barrage of rhetorical questions: "What is there in that union that people distinguish from the amorous union? The church, which claims the right of consecration, admits that it does not know yet."gl The heart of the problem, in any case, was the social utility of marriage. "What place does it have in society or commerce?"92 Finally, the denouement: "our moralists, who preach the domestic virtues, have forgotten to define these things for us."193 This, like many of proudhon's questions, was a legitimate province of exploration, but his answers hardly scratched the surface. Moreover, in this instance, the element of poignancy was missing. Proudhon, unlike Kierkegaard and Nietzsche, who also discussed this issue, was not only married, but was devoted to his wife and children.

Proudhon's attack on modern life was energetic and appealing to young radicals. He seems to have drawn many of the foremost minds of Europe into the web of his rhetoric, and they, for their part, were of ten enmeshed in it forever. Even the incisive Marx, bourgeois society's most impressive critic, was, for a time, drawn to Proudhon.

The episode began when Marx, in the early stage of his

90 proudhon, De la justice, $1,35$.

91 ibid.

92 ibid.

93 lbid. He meant here, the family and parenthood, as well as marriage. 
career in Cologne, read and appreciated What is Property? As Sir Isaiah Berlin, one of his most astute biographers has written, anything that carried a revolutionary spark appealed to the young Marx, in those days.94 When he arrived in Paris, in 1844, he established a friendship with Proudhon, and in Die Heilige Familie, his attack on the Bauer brothers, made a stirring thirty-four page defense of Proudhon against Bruno Bauer.95 In 1845, at the behest of the Paris police, Marx left for Brussels. In 1846, fervently hoping to keep the lines of communication among Socialists open, he, Engels and some few of their German colleagues, set up the committee of Communist Correspondence. Marx desired that Proudhon be its Paris representative, and wrote him a letter to that effect. As Wolfe reports, Proudhon was anxious for an open discussion, but put off by a scurrilous postscript in the letter, attacking Karl Gruen, a socialist journalist, who was teaching Proudhon German.96 Proudhon ignored Marx's warning about Gruen, and about the Committee of Correspondence wrote:

Let us seek together, if you wish, the laws of

society, the manner in which these laws are

94 Berlin, Marx, 112 .

95 See Bertram D. Wolfe, Marxism (United States: Delta Books, 1967), 258: Wolfe's account of the particular's of Proudhon's and Marx's relationship is much more satisfactory than Berlin's.

96/bid., 260. This version contradicts accounts appearing elsewherewhich convey the impression that Marx asked Proudhon to collaborate with him in the same way as Engels. Wolfe's version, I think, is more acceptable. 
realized, the process by which we shall succeed in discovering them. But for God's sake, after having demolished all the a priori dogmatisms, do not let us in our turn dream of indoctrinating the people.

I applaud with"all my heart your thought of bringing to light all opinions; let us carry on a good and loyal polemic; let us give the world an example of a learned and far-sighted tolerance. But let us not, because we are at the head of a movement, make ourselves the leaders of a new intolerance... Let us gather together and encourage all protests, let us condemn all exclusiveness... . On this condition I will gladly enter into your association. otherwise - no! 97

By now Marx's patience had worn out. One simply did not ignore his advice, or lecture him with regard to his intellectual responsibilities. So, when Proudhon submitted for his criticism The Philosophy of Poverty, Marx took the opportunity to systematically and sarcastically ravage the book and its author, in a retort entitled the Poverty of Philosophy, ending their relationship forever, but not, as Marx also intended, Proudhon's career and influence in France. In June of 1848 , Proudhon was elected overwhelmingly to the Constituent Assembly of the revolution. Next, when his book, written while in the prison to which Louis Napoleon had consigned him for sedition, appeared on the market it sold out six editions in six months... And, when the first International was formed, Márx discovered that Proudhon was much more influential in it than he was. 98

97English translation published in Dissent (Winter, 1958). originally collected in P. J. Proudhon, Confessions d'un revolutionaire.

98 Wolfe, Marxism, 262. 
Marx, however, had more than personal differences with Proudhon. As both Berlin and Volfe point out, Proudhon was not up to Marx's intellectual standards (to Marx's mind, hardly anyone was). Actually, the real problem was the lack of similarity between the German and French intellectual traditions. Marx discovered his contempt for Proudhon was based on his lack of understanding of the dialectic and of Hegel.99 Proudhon's Hegelei, imparted to him mostly by Gruen, was rudimentary, to say the least. It can be argued that Hegel's idea of God, when turned over made Marx incapable of appreciating anything resembling a God-reliant system, so that Proudhon's use of the dialectic appeared to him both irrelevant and incomplete. 100

Marx had gotten, from Hegel, the concept of the Cunning of Reason, which meant, in Hegel's terms, that the idea of Reason, which is, simply, the complete plan of development that the Weltgeist traverses through history, would be rationally fulfilled by calling into play irrational forces, namely human nature and passions.101. The cunning of Reason is, thus,

990 the other hand, Proudhon at least tried to understand German philosophy. Most French intellectuals ignored it to the point that Jean-paul Sartre could write of his student days, a hundred years after Hegel, that "the horror of the dialectic was such that Hegel was unknown to us." Search for a Method (New York, 1963).

100 see, particularly, Berlin's discussion of the intellectual differences between the two, and $R$. C. Tucker, "The Cunning of Reason in Hegel and Marx," Review of Politics, XVIII, (July 1956), 269-295.

101 Tucker, "The Cunning of Reason," 269 and 271. 
fiat "'particular purposes: of the individual are made to arve the 'substantial wil " of the World Spirit.1102

In llarx's hands, this fors:, which had, for Hegel, been anifested as the quest $f(-$ mastery by Alexander the Great and Julius Caesar, became she quest for mastery by the capitalist rhlch would eventually leas to the destruction of bourgeois society, which was at the end of Marx's dialectic.103

Now Proudhon, like the Utopians, had failed to appreciate this factor. He felt that dialectical action in history was the amelioration of social conditions in a fundamentally unchanged and unchanging moral and ethical context. 104 He rejected the idea of the separation of economics and ethics which, in part, the Cunning of Reason had caused Marx to do, in the belief that they had no relevance to each other in the socio-economic metamorphosis of human history. Proudhon, then, saw poverty only as a moral evil, to be alleviated. In The Poverty of Philosophy, Marx ridiculed this position, lumping Proudhon with the Utopians. "They see in poverty only poverty, without seeing therein the revolutionary subversive side which will overturn the old society," he said.105 Another social critic and revolutionary with whom Proudhon came in contact, and with whom he had an altogether happier

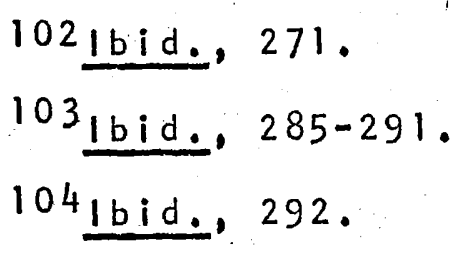

105 Karl Marx, The Poverty of Philosophy (Moscow: Foreign Language Publishing House, 195?), 136-37. 
relationship, was the anarchist, Michael Bakunin. As the British historian, E. H. Carr106 points out, there was a certain reciprocity here. Bakunin, according to Carr, originally introduced Proudhon to Hegel, and instilled in him the adherence to his credo, "the passion for destruction is a creative passion," which Proudhon used to set the tone of The Philosophy of Poverty; "Destruam et Aedificabo," read the work's epigram.107 Carr believes that, for his part, Proudhon, "more than any man.. Was responsible for transforming Bakunin's instinctive revolt against authority into a regular anarchistic creed."108

Together with many of his antecedents, many of his contemporaries, and not a few of his successors in nineteenth century European thought, Proudhon succeeded in creating an attitude of ambivalence toward the function of most of the traditional socio-economic institutions of western society. That is to say, in attempting to create comprehensive critiques of middle class society, these men built into nineteenth century thought, a basic irresponsibility, a

106E. H. Carr, Michael Bakunin (London: MacMillan and Co., Limited, 19.37), 130-T31. A comparison of Carr's attitude toward Proudhon in this book and in his Karl Marx (London: J. M. Dent \& Sons Ltd., 1938), reveals a discrepancy which can only be construed to undermine his scholarship. In the former, Carr has fulsome praise for Proudhon, in the latter, he refers to him as a pedestrian thinker. It appears, also, that, in Bakunin, Carr has misread Proudhon's philosophy, with reference to God. See especially p. 130.

107 Carr, Bakunin, 131.

108 lbid. 
promiscuity (which ought to be recognized as a hallmark of the entire century's intellectual accomplishment, but especially of romanticism) that allowed later students to plunder their works for support in nearly anything. One has only to recall, for instance, Lenin's unscrupulous use of Marx's words against his enemies, 109 or the Nazis' use of Hegel and Nietzsche to give intellectual credence to their claims, to grasp the meaning here.

In Proudhon's case, Jean Juares, the great French socialist, is able to place him squarely in the mainstream of French socialist history, 110 while J. Salwyn Schapiro, an American scholar who has done much work in the history of Western political traditions, can, with no special pleading, call proudhon a "harbinger of Fascism."111 In discussing Proudhon's connection with the theory of modern liberalism, one scholar has said that proudhon was acute enough to draw from the upheavals of his times the conclusion that his thought must attack the fundamental assumptions of nineteenth century philosophy, including the legacies of the eighteenth century, optimism, and faith in the natural harmony of interests. 112 Proudhon believed that social antinomies -

109 see Wolfe, Marxism, for many interesting incidents. of this sort.

$110 \mathrm{Jean}$ Juares, ed., Histoire socialiste, VII-VIII, (Paris: Jules Rouff and company, ?), 433-442.

111 see the article of that title which appears in the American Historical Review, 50, (July, 1945), 714-737.

112 Frederick M. Watkins, "Proudhon and the Theory of 
the uniting of opposites - had to be created. In creating social antinomies, opportunities for social conflict are aso created, but in doing so, he believed, human reason would "enable interdependent individuals and groups to discover mutually acceptable bases for common action."ll3 The point of this is that rational (read social) justice would emerge as men discovered that it (justice) was the only means of ameliorating social discrepancies. In this critic's opinion, this is an important principle of modern liberal thought and proudhon stands, therefore, as one of its fathers.114

Schapiro, on the other hand, is able to find in Proudhon, 115 strong traces of Fascist tendencies, particularly antisemitism-(he made remarks to the effect that the Jews were ruining the country) and racialism (he declared the Negro the lowest racial group, and defended the south in the American civil war).116 In fact, Schapiro notes that Proudhon went so far as to glorify war, in La Guerre et La Paix. 117

Schapiro finds that these notes were not forgotten later on;

Modern Liberalism," Canadian Journal of Economics and Political Science, XIII, (February to November, 1947), 432. It seems to me that, as noted earlier in this essay, Proudhon had not a little of that optimism himself.

\section{3 lbid., 434. \\ 114 lbid., 435.}

115 In sources to which the present paper does not have access, notably Résumé de la question sociale, La Guerre et la paix, and Proudhon's letters.

116 schapiro, Harbinger, 728-729.

117 lbid., 729-730. 
on the contrary. Proudhon was drawn over to the side of arch conservatism by Edouard Drumont and Charles Mauras of the Fascist party. Action Frangaise. 118

Proudhon died on the 19th of January, 1865. On learning the news, the Baron D'Ambres made this entry in his diary:

Proudhon died yesterday. 119 He was, as Girardin rightly said of him, a great denier. Negation was the form his thinking took. That is why I have no sympathy with his work, which is rather destructive than anything else, because his mind exerted itself more to demolish society than to improve it. He lived too much by the brain and not enough by the eyes. He devised systems, but he made no attempt at practical solutions of social questions that are so difficult, complex, and delicate. or, when he did give any solutions, they were almost always paradoxical. His strong point was to keep denouncing - that is describing minutely the vices of the existing organization. 1 do not say he was lacking intelligence. I do not even say he was useless. I do say that he succeeded in creating nothing directly practical.120

On January 23,1865 , they buried D'Ambres' great negator. 121

The mourners who followed the cortege to the cemetery of Passy were some six thousand strong - the nameless, faceless proletaires of Paris, as well as the pens and swords of 148. Suddenly a drum throbbed from around a corner. Perhaps the Emperor's troops were going to ruin this last tribute. The crowd formed a solid wedge, braced for any eventuality.

118 lbid., 732 .

119 The date of this entry is January 30, 1865. D'Ambres had his dates confused.

120D! Ambres, Memoirs, 2, 302 .

121 This account is from Woodcock, Proudhon, 268-269. 
51

As the troops halted, Amadee Langlois, Proudhon's old friend, who had been at his deathbed, approached their commander. Proudhon is dead and we are going to bury him today, he explained. But the commander was at a loss. He was on his way back to his barracks. He could not change his route. Politely, the crowd parted: the troops passed. Then from one of those hedges of men, a voice cried, "beat the salute." The commander raised his sword, the drums tabooed the funeral march. All heads were uncovered. The regiment marched on, presenting arms. 


\section{CHAPTER V}

\section{T. S. ELIOT: THE ARTIST AND THE CRITIQUE OF MODERN CULTURE}

Thomas Stearns Eliot was a poet and critic of profound influence on most parts of contemporary English and American literature. In the capacity of critic, he was able to fashion for himself a career that delved authoritatively into modern culture in all its aspects. In the role of poet and playwight, he carried on his cultural criticism, sometimes acerbically and sometimes poignantly delineating the failures of modern life. It is, in fact, his depth of feeling for the discrepancies between modernity and cherished tradition that energized Eliot's unique genius. That is to say, the legacy of T.S. Eliot was a corpus of words dedicated to the salvation of the sacred artifacts of European culture from the defile of bourgeois society. The man of literature had risen to defend the sources of his art.

T. S. Eliot was born in St. Louis, Missouri, on September $26,1888.122$ He was the youngest of seven children

122 To this writer's knowledge, no standard biography of Eliot is available. Material of this sort must be gleaned from several places, so that a complete picture can be obtained. For this, at least three sources can be recommended. They include, Alan Holder. Three Voyagers in Search of Europe (Philadelphia: University of Pennsylvania Press; 1966); 
of the family of Henry Ware Eliot and Charlotte (Stearns) Eliot. On both sides, his family had descended from New England Puritan stock, although Henry and Charlotte Eliot were of the Unitarian faith. Henry Eliot was a prosperous brick manufacturer who also sold mules.

Apparently, the first piece of literature to interest young "Tom," as he was known to his family, was Fitzgerald's Rubaiyat, which he picked up at home when he was fourteen.123 From 1898 to 1905, Eliot attended Smith Academy in St. Louis, where he studied classical languages and history, modern languages and mathematics, and English and American history. This period he thought the most important of his education because he had learned what he considered the essentials, 124 After Smith, he went to Harvard where, from 1906 to 1909, he did undergraduate work. He also obtained a masters degree there in 1910. It was while doing graduate work that he began work on "The Love Song of J. Alfred Prufrock," which was ultimately published in 1917. After finishing his masters degree, he began work on his doctorate at Harvard, and continued it at the University of Paris where Alain Fournier was his tutor. While at the University of Paris, Eliot attended the lectures of Henri Bergson.

Philip R. Headings, T.S. Eliot (New York: Twayne Publishers, Inc., 1964); and Ailen Tate, ed. T. S. Eliot, The Man and His Work (New York: Delacorte Press, 1966). The biographical information presented above is from these sources.

123 Headings, Eliot, 19. 124 bid. 
Eliot received a traveling fellowship for 1914-1915, which he used to spend some time in Germany. The outbreak of World War 1 at the end of the summer, however, changed his plans. He returned to England, enrolled at Overton College, oxford, and read the German phenomenologists Meinongand Husserl, and Aristotle.

It was at this point also, that Eliot's stay in England became permanent. Whether by chance or design, it would be seventeen years before Eliot again saw America, by which time he had become a British subject. And in one sense, in light of his background and the concerns of his literary career, his abandonment of America was only logical. For he proved to have been-in flight from the disintegration of tradition after the Civil War, and from the specter of radical Protestantism, Puritanism, that oppressed American culture. 125 in fact,

125 For this valuable insight, the writer is indebted to Ir. Frank M. Szasz, instructor in American Intellectual and Cultural History at the University of New Mexico, Albuquerque, liew Mexico. Mr. Szasz contends that the disintegration of tradition in America after the Civil War disoriented and displaced the American aristocracy, that the business classes noved in and usurped the American dream permanently dislocating the tradition-bound upper classes. Furthermore, he contendss that the harshness of the puritan vision was always a difficult thing for any American author to deal with, that in the earlier rineteenth century it was cloaked in allegory, as in Melville's "oby Dick, that in the later nineteenth century, most American Mrters turned to Europe for methodology, as the Naturalists, and that it was this combination of circumstances which caused iuch Writers as James, Pound, Eliot, Hemingway, and Fitzgerald la abandon America, even if only for a time. These views - re substantially corroborated in Holder, Three Voyagers, $\therefore$. 1, 19-83, Sidney Mead, The Lively Expe riment (New York: *rper \& Row, 1963). 10; and Morris Freedman; "The Meaning of i. S. Eliot's Jew," South Atlantic Quarterly, 55, (April, 1956),
19-206. 
his odyssey could not have been more symbolic of his quarrel with America: from St. Louis, his merely physical birthplace, a city of ambiguous tradition, neither Southern nor Northern; a brief sojourn in New England, the home of his immediate forbears, yet an uncomfortable haven; in the end, to England, a spiritual refuge, his "ancient birthplace d" 26 As one critic has put it, his flight was the "northeast imigration homeward, perfectly reversing the course of the rugged, restless earlier Puritans."127

It was in September of 1914 that Eliot met Ezra Pound, in London, through his friend and Harvard classmate, Conrad Aiken. While Pound's influence on Eliot was not germinal (Eliot had made contributions to the Smith Academy Review and the Harvard Advocate which bore the mark of his later poetry) it was nonetheless considerable and Eliot always felt deeply in his debt, especially for the guidance Pound gave him from 1915 to 1922.128 pound and Aiken set about trying to find publications that would print Eliot's work, and after a good deal of hounding, Harriet Monroe was persuaded by Pound to accept "prufrock" which thus appeared in her magazine, Poetry, in 1915.129

126 Freedman "Eliot's JeW," 203.

127 lbid.

128 Headings, Eliot, 26-27.

129"prufrock" was published by Eliot in 1917 in Prufrock and other observations which sometimes leads to confusion about its original date of publication, but, it certainly appeared in Poetry first. 
From time to time, in the period just after the war and through the early twenties, Eliot was forced to seek fulltime employment and ignore or slight his art. He worked at. the Faber publishing house and at Lloyd's Bank at this time, staying with Lloyds until 1925. Still, he had literary projects in the works, including the editorship of Criterion, the literary periodical he nurtured for seventeen years, and by this time, his career in art was full-fledged.

\section{Eliot's famous remark, "I am a royalist, an Anglo-} Catholic, and a traditionalist," was much more than a pasing comment. It was the essence of his feelings about politics, literature, and every aspect of culture which comprised the world in which he lived. Moreover, it is for the critic a gauge by which may be measured the depth of his disappointment with modern life. He was a royalist, an Anglo-Catholic, and a traditionalist in a time and place in which holding those beliefs was dangerously close to sentimentalism, and to maintain them in the face of the realities of the twentieth century was quixotic and brave. Only a man of deep conviction could have succeeded with them.

Eliot's diagnosis of bourgeois society had developed as early as 1910, when he began. "The Love Song of J. Alfred Prufrock."130 In "prufrock," Eliot initiated one of his

130 See John C. Pope, "Prufrock and Raskoluikov Again: A Letter from Eliot," American Literature, 18, (January, 1947), 319. Here Eliot straightened out the controversy over the actual time of conception of "prufrock." 
favorite themes, one which was to recur often in his work, the fallen, paralyzed, useless aristocrat, trapped and immobilized by bourgeois society. One critic has theorized that, in fact, Eliot took his inspiration for the character of Prufrock from the archtype of the aristocratic failure, Henry Adams. 131 Whereas most commentators have assumed that the climactic lines of "Prufrock" were from Hamlet $(11,2,204$ : "for yourself, sir, shall grow old as 1 am, if like a crab, you could go backward") George spangler believes that a more revealing parallel is to be found in The Education of Henry Adams where Adams writes, "one was almost glad to act the part of the horseshoe crab in Quincy Bay, and admit that all was uniform - that nothing ever changed . . 1132 "I should have been a pair of ragged claws / scuttling across the floors of silent seas" Prufrock muses, paralleling Adams' thought. 133 The longing to regress

131 George M. Spangler, "The Education of Henry Adams as a Source for 'The Love Song of J. Alfred Prufrock, Tll Notes and Queries, 15, (August, 1968), 295. Incidentally, the name of J. Alfred Prufrock has been traced by a diligent scholar to a St. Louis furniture store owner. See B. K. Martin, "Prufrock, Bleistein and Company," Notes and Queries, 14. (July, 1967), 257.

132 spangler "Henry Adams and 'Prufrock," 295. See The Education of Henry Adams (Cambridge, Mass.: Riverside Press, 1918), 448. The only objection to this theory is that "prufrock" was published before The Education, which appeared in 1918. Spangler, however, notes that the Massachusetts Historical Society in Boston had a pre-edition available when Eliot was a student at Harvard, and that it was not unlikely that a young man of Eliot's interests should have read it. See Spangler, 295.

$133 \mathrm{~T}$. S. Eliot, "The Love Song of J. Alfred Prufrock," in The Complete Poems and Plays. (New York: Harcourt, Brace 
:o a simpler state is not all the two works share. Both

are concerned with the domineering woman and sexuality. 134 in "prufrock," moribundity and paralysis are crucial themes; they were obsessions with Adams.135 it was, therefore, probably no coincidence that Eliot, reviewing The Education for Athenaeum in 1919, saw Adams as another Prufrock. 136 In "Prufrock," Eliot's vision was one of a man "pinned and wriggling on the wall," and by 1922, he was so thoroughly convinced of that vision and of the sterility of modern culture, that he published that year the most comprehensive critique of social and cultural conditions ever attempted in a single poem. This, of course, was "The Wasteland," and it became almost instantly a classic statement of the Weltschmerz of the Twenties. In "The Wasteland," Eliot's method was to juxtapose the rich, purposeful culture of the past with a sordid and arid present.

He began his first section by again exposing the irrelevance and gracelessness of the twentieth century aristocracy.137 "The Burial of the Dead" does lay to rest

and World, Inc., 1952), 5.

134 see especially Ch. 30 of The Education, 436-448. 135 spangler, "Henry Adams and 'Prufrock," 295. 136 ibid.

$1371 t$ is not the author's intention here to provide a detailed analysis of "The Wasteland," only to point out its relevance to the general topic. "The Wasteland" has, however, probably received more and better critical treatments than any other poem in the history of literature. Some, which have been of use to this paper, are found in: Genesius 
this dead institution. Anymore, it says, the aristocracy is just like the human appendix: Serving no useful purpose, but once in a while causing trouble. Marie only reads and goes south in the winter, an example of the blank existence of a blank segment of society. Eliot had apparently read the autobiography of Countess Marie Larisch, whose life, and the lives of those relatives, closely parallels what happens or is implied in the poem. 138 Most of her family were notable members of the House of Habsburg and only two seem to have had any semblance of purpose to their lives. Marie herself was blamed for the tragedy of Mayerling. One of her relatives in fact, an archduchess, somehow acquired the delusion that she had swallowed a sofa which was permanently lodged in her head. She was afraid to leave her room for fear the ends would stick in the door jambs.139 The obvious contrast with this group of people was the earlier aristocracy which was possessed of some degree of responsibility, usefulness, and charm.

Jones, Approach to the Purpose (New York: Barnes and Noble, Inc., 1964); Leonard Unger, T. S. Eliot, Moments and Patterns (Minneapolis: University of Minnesota Press, 1956); Sean Lucy, T.S. Eliot and the Idea of Tradition (London: Cohen and West, 1900); Thomas McGreevy, T.S.ETiot (London: Chatto \& Windus, 1931); Allen Tate, ed., T.S. Eliot, the Man and His Work (New York: Delacorte Press, 1966); FeiPai LU, J.S. ETiot, the Dialectical Structure of His Theory of Poetry (chicago: University of Chicago Press, 1966); and Hugh Kenner, "Notes Toward the Definition of Culture," Hudson Review, 2, (Summer, 1949), 289-94.

138 George L. K. Morris, "Marie, Marie, Hold on Tight," Partisan Review, 21, (March-Apri1, 1954), 231 . 139 lbid., 233. 
Next, when Madame Sosostris tells the protagonist's

fortune ("There, said she, / is your card, the drowned

Phoenician sailor. . ,") she reveals a facet of the general

theme, the betrayal of the religious order of the past by

the twentieth century prophet. 140

Madame Sosostris, famous clairvoyante,

Had a bad cold, nevertheless

is known to be the wisest woman in Europe,

With a wicked pack of cards.

The wisdom of the ages, the light of the world, coming down

to us in a pack of cards manipulated by a sniffiing gypsy

is represented as the ultimate perversion of the godhead. 142

In the second section, "A Game of chess," we find that

love is also "perverted" and meaningless in this century.

Eliot used Philomela, the violated woman of mythology, as

the basic metaphor of this observation. She was raped by her

sister's husband, but she escaped and turned into a nightingale;

thus, there was no love. Eliot suggested that by the same

process, rape - but rape by scientific examination - love

changed in this century.

My nerves are bad tonight. Yes, bad. Stay with me.

'speak to me. Why do you never speak. Speak.

'What are you thinking of? What thinking? What?

1 never know what you are thinking. Think. 1143

140Eliot, "The Wasteland," Complete Poems, 38.

141 ibid.

142 The Hanged Man represents Christ ("I) do not find the Hanged Man.") lbid., 38-39.

143 1bid., 40. 
Included in this section to remind of the sterility of everything is a reference to the "Shakespherian Rag" which was neither "elegant" nor "intelligent."

"The Fire Sermon" presents three important symbols: Tiresias, Mr. Eugenides, and the "young man carbuncular" and his lover. Tiresias watches the two lovers and by his presence relates the act of lipve to the past. Contemporary with all history, Tiresias shows us the ludicrous aspect of contemporary liasions blighted by twentieth century adjectives such as "automatic." The violet and blue of Mary prounounce the sordid, unholy aspect of the affair.

Mr. Eugenides, the Smyrna merchant, offers a cheap representative, an unreasonable facsimile of the ancient Syrian merchants from whom he is descended. These traders were instrumental in the spreading and development of the culture of the West, but Eugenides is unshaven, unctuous, and homosexual.

"Death by Water" demonstrates to a small extent (other themes are more important,) that twentieth century man takes no risks, makes no attempts at adventure. Yet, Phlebas, the Phoenician merchant, who did seek adventure, "was once handsome and tall as you."

In the fifth and last passage, "What the Thunder Said," Eliot did not allow the past to finally bury the present. Instead, he found hope for the survival of the culture, a chance for his time to take its place as heir, successor to the past. The chance, however, depended largely on the ability 
to return to the more meaningful values of the past. Where Eliot's teacher, Pound, saw "a botched civilization," Eliot saw hope, but hope only in return. The water, the rain, representing the return of the wasteland to fertility was possible, but the thunder only admonishes thus:

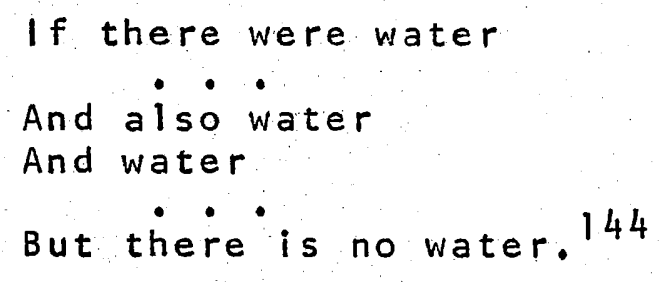

"The Wasteland" was Eliot's ultimate comment on the character of his times. In it he marshalled the resources of the whole history of western culture so as to most thoroughly indict modernity. But if it was his ultimate comment, it was not his final one. In 1922, also, Eliot launched his periodical, The Criterion, which was for the next seventeen years to be a major showcase of his ideas. He had seen N. R. F. energize French intellectual life, seen Pound breathe I ife into The Egoist, and he was eager to stamp the mark of his own mind on his own journal. In discussing the place of Criterion in Eliot's thought, one scholar has said,

ambition drove Eliot in successive mutations as it drove his Becket [in "Murder in the Cathedral"], but not ambition for the regalia of editorship - rather the honorable, desperate and irremediable ambition to pursue and cry a conviction, to be a preacher, a Savanarola (his mother's hero), and to change the world.

144 bid., $47-48$ 
He wanted to do what Arnold had credited Newman and the oxford Movement with doing: 'Swell the tide of secret dissatisfaction which has mined the ground under the self-confjdent liberalism of the last thirty years.' 145

Through the years of its existence, Criterion was a forum for a wide range of opinions on a variety of subjects from literature to religion to politics. Eliot opened its pages to unknown as well as established writers, and gave a good deal of space, especially, to conservative opinion. His own contributions were limited to book reviews and short commentaries usually concerned with some current sophisticated gossip of interest to his readers, but occasionally he inserted an article of his own which dealt at some length with a political or social problem; these endeavors, moreover, were usually attended by assertions of political innocence. In 1928, an interesting episode unfolded on the pages of Criterion. Eliot the artist was obliged to turn polemicist for a time as he carried on a spirited defense of his political hero and personal friend, the French conservative, Charles Maurras, founder of the right wing group Action Francaise. Maurras had been attacked by Leo Ward in a book entitled The Condemnation of the 'Action Francaise. 1146 in a series of articles in Criterion, Ward and Eliot traded opinions

145Herbert Howarth, "T. S. Eliot's Criterion: The Editor and his Contributors," Comparative Literature, II (Spring, 1959), 97.

146 Leo Ward, The Condemnation of the Action Frangaise (London: Sheed and Ward, 1928?). 
on Maurras and his organization, Eliot contesting first of all Ward's charge, that Action Francaise had "'instilled a pagan spirit into some thousands of Catholic youths - a spirit of real national and class hatred.11147 He, Eliot, had, on the other hand, read Maurras for eighteen years and had only been drawn closer to his religion. 148 Furthermore, he predicted that "if anything, in another generation or so, is to preserve us from a sentimental Anglo-facism, it will be some system of ideas that has gained much from the study of Maurras."149

Ward, however, was not to be easily turned aside. In an article which appeared alongside one by Eliot under the general title "LlAction Française," Vard reiterated his original charges against Maurras, emphasizing his earlier theme by labeling him a purveyor of racial, national, and class hatred, as well as a reactionary whose ideas had been lifted whole from De Maistre, and who was, in the end, only an imitation of Mussolini.150 Eliot's rejoinder complained of a difference in values between Ward and him, and rather weakly differentiated between Maurras and Mussolini. 151

$147 \mathrm{~T}$. S. Eliot, "Action Frangaise M. Maurras, and Mr. Ward," Criterion, 7. (March, 1928), 195.

148 lbid.. 202.
149 lbid., 197.

150 Leo Ward, "L'Action Francaise, a Reply to Mr. Eliot," Criterion, 7, (June, 1928), 371-72.

151 T. S. Eliot, "L'Action Française, A Reply to Mr. Ward," Lbid., 372-376. 
Eliot's idea of cultural decadence had apparently led him to the Maurrasian vision of the conservative political reconstruction of society, in much the same way, as stuart Hughes commented, many young Frenchmen of Eliot's generation had been attracted to Maurras. At any rate, he continued to worry about politics and culture, now invoking the fears and the pessimism of Valery or spengler, now hoping for the rise of a "new European consciousness," which would breathe new life into the "small and isolated cape on the western side of the Asiatic continent."152 if Action Française was not the most impressive political movement of the century, it seemed to promise a reassertion of values which would produce this new consciousness - a reduction of democracy, a tough and unsentimental Christianity, a redefinition of culture.153 In this connection, he wrote of democracy, "a real democracy is always a restricted democracy, and can only flourish with some limitation by hereditary rights and responsibilities. The United States of America, for instance, were more or less democratic up to 1829, when Andrew Jackson became president. . . "154 Not surprisingly, Ernst Curtius, in a 1929 article foo Neue Schweizer Rundschau, bracketed Eliot with Maurras as "'representative of the 98. 152T. S. Eliot, "A Commentary," Criterion, (August, 1927),

${ }^{153}$ T. S. Eliot, "The Literature of Fascism," Criterion, 8, (December, 1928), 280-290.

154 Ibid., 287. Jackson was commonly and erroneously thought to have ushered in the era of the common man in American politics. 
restoration, the "conservative revolution."11155 They all shared, according to curtius, the sense of classic form which was the "reflection of eternal strength. 11156

Through Criterion Eliot waged a campaign against most of the irritating events of modern life, from the destruction of historic buildings to the dearth of theater in London (which he attributed to the lack of taste of the middle class.) on January 1, 1939, however, publication ceased. The onset of war had negated the premise on which criterion existed; that was "the supposition of a comity of nations sharing and upholding a tradition."1157

Eliot's preoccupation with politics and culture derived basically from a desire to preserve completely an ordered, homogeneous cultural tradition for the benefit of the artist, who could then easily integrate his imagination with the past and thus create art that would carry forward and strengthen the culture's traditional values. For Eliot, this was a fundamental tenet of good art. Art must spring from its culture and then return to it a cultural dividend, as it were; this dividend would consist in the contribution to the culture of novelty. In the famous essay, "Tradition and the Individual Talent," published in 1919, he laid down this idea as a principle of criticism.

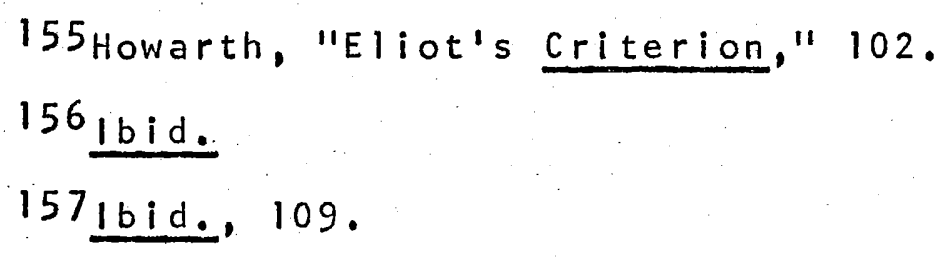


You cannot value him [the artist] alone; you must set him, for comparison and contrast, among the dead. I mean this as a principle of aesthetic, not merely historical criticism... . The existing order is complete before the new work arrives; for the order to persist after the supervention of novelty, the whole existing order must be, if ever so slightly, altered. . and this is conformity between the old and the

Here homogeneity became an important factor. Novelty was to be allowed, really, only on the paradoxical basis of its conformity with the old. Moreover, to insure the purity of the cultural tradition, certain social conditions had to be met. Those conditions were laid down by Eliot in the Page-Barbour lectures at the University of Virginia, delivered in 1933, and were later collected under the title After Strange Gods. 159 He said

the population [of a nation that wished to have a viable culturel should be homogeneous; where two or more cultures exist in the same place they are likely to become adulterate.160 What is still more important is unity of religious background; and reasons of race and religion make any large number of free-thinking Jews undesirable. There must be a proper balance between urban and rural, industrial and agricultural development. And a spirit of

158T. S. Eliot, "Tradition and the Individual Talent," in his-Selected Essays (New York: Harcourt, Brace E World, Inc., (932), 4-5.

${ }^{159}$ T. S. Eliot, After Strange Gods (New York: Harcourt, Brace \& World, Inc., 1934).

160 Here Eliot included a footnote (Number 1 in this edition) saying, "or else you may get a caste system, based on original distinctions of race, as in India: which is a very different matter from classes, which pre-suppose homogeneity of race and a fundamental equality. But social classes, as distinct from economic classes, hardly exist today." Ibid., 20. 
excessive tolerance is to be deprecated.161

The intemperance of the foregoing remarks indicates the extent to which Eliot's sensibilities had been offended by the modern world. He was uncomfortably aware, for instance, of the exodus in the first part of the century of large numbers of people from eastern Europe, most of whom were Jewish. "Burbank with a Baedeker: Bleistein with a Cigar," shows the typical situations into which Eliot put Jews.162 Sir Ferdinand Klein of the poem is a ludicrous character with a certain unsavory sexuality.163 The Burbank character, on the other hand, is a vacuous, insipid, middle class Englishman with no competence in anything, especially not culture (the Baedeker is a tourist's handbook) and decidedly not sex (he cannot even succeed with princess volupine, the supine voluptuary).

In Eliot's view, culture and society nurtured one another, each playing a part in the determination of the character of the other. If society abandoned its political and social traditions, it risked losing contact with the cultural values of the past that had enriched existence in the society and made it viable. And if society lost contact with

161 lbid.

162Eliot, "Burbank with a Baedeker: Bleistein with a cigar," Complete Poems, 23-24.

163 see Morris Freedman, "The Meaning of T. S. Eliot's Jew," South Atlantic Quarterly, 55, (April, 1956), 199-206, for a complete and dismaying analysis of Eliot's use of Jews in his poetry and drama. 
69

its cultural heritage, it could not add to the culture, sep it alive. This would be the ultimate tragedy for the artist who could only exist in the living matrix of the culture with which he identified. Indeed, in bourgeois society Eliot detected these very symptoms. For him as an artist, the eclecticism and diversity of modern life, the insensitivity of the bourgeois to his cultural treasures, the disintegration of traditional social forms, the opening up of society to alien elements, seemed to be the initial steps to this eventual tragedy. The result was that his career was dedicated to exposing it. 


\section{CHAPTER VI}

EMMANUEL MOUNIER: THE "TRAGIC OPTIMISH"

OF THE MODERN CATHOLIC

Candor compels the writer to admit that perhaps

Emmanuel Mounier is not the most perfect example of cultural despair to be found in European Catholic thought. Certainly

G. K. Chesterton or Hilaire Belloc display more of the characteristics to which we have alluded already as being indicative of the syndrome. Indeed, their unhappiness in the modern world seems to have gone much deeper than Mounier's. Charles Maurras, or Maurice Barres, or even Charles Peguy, were French Catholics who present thoroughgoing portraits of cultural despair. They might well have served as illustrations of our concerns.

On the other hand, Emmanuel Mounier's intellectual career is characterized by something that would possibly have been harder to show in any of the others, and yet is definitely a valuable dimension to add to this discussion. That is to say, Mounier represents the attraction of the Catholic vitalist to the debate over modern society. Following in the footsteps of Henri Bergson and his Neo-Thomist followers, Mounier tried to delineate, through his philosophy of personalism, the potential of the human spirit to achieve 
the perfection of the material world. As personalism was art of the larger phenomenon of vitalism, vitalism was part of a still larger phenomenon, the revolt against the naive, scientistic positivism of the nineteenth century. Vitalism went on, in France, to become connected with the disappointed, disoriented, Catholic thought of the early twentieth century. Looking for regalvanization in a time when it was trying to recover from a dearth of fresh ideas, French Catholics such as Bergson (who was, of course, Jewish, but nonetheless a central figure in Catholic thought, ) Jacques and Raissa Maritain, the Jesuit paleontologist, Pierre Teilhard de Chardin, and Mounier posited this perfectability of man and his world through the invocation of his spiritual attributes, against the old positivist strictures of a static and mechanical world subject only to rational perfectability." Mounier's personalism reflects this new thinking, but Hounier also felt that the first step was to overcome bourgeois society, which he saw as the root cause of all alienation. He was therefore preoccupied with the economic and political criticism of democracy, and was thus drawn to the analysis of Marxism. It is not difficult to see then, how his unique blend of spirituality and material philosophy can serve as a more than adequate illumination of the Catholic mind in reaction to modernity.

Emmanuel Hounier was born in Grenoble in 1905.164 He

164 To this writer's knowledge, there is no large unit 
attended the University from 1924 to 1927 , studying under the direction of Jacques Chevalier, who later became Minister of Information in the Vichy regime. In the fall of 1927, he went to Paris to take the agregation, the competitive examinations for teaching posts at state universities. He ranked second to Raymond Aron in philosophy, in 1928. Remaining in Paris, he was associated with a Lazarist priest, Father Pouget, and was a regular member of a discussion group brought together by Jacques Maritain. In 1931, as the result of a fascination with charles Peguy, Mounier and two collaborators, George Izard and Marcel Peguy, published a book entitled La Pensée de Charles Peguy. He taught philosophy for a year at the Lycée de Saint-oner and at a private school, Collège Sainte-Marie de Neuilly $(1931-32)$ and attempted to begin his doctoral dissertation through the Sorbonne. As early as 1929, however, Mounier had reached a decision not to commit himself to a teaching career. As Roy Pierce has put it,

deeply convinced that the times in which he 1 ived represented a profound crisis of civilization, depressed at the extent to which he believed christianity was implicated in the social evils which characterized that crisis, persuaded that there were no adequate means of expression for the young generation, Mounier began to think of

of biographical information available on Mounier. The above account of his life was gleaned from an adoring forword in Mounier's Be Not Afraid (New York: Sheed and Vard, 1962) V-XXV, written by Leslie Paul, an English personalist, and Roy Pierce's more scholarly account in his Contemporary French Political Thought (London: oxford University Press, 1966). 
establishing a review. 165

Having modeled his life on Peguy's he wanted to create something like Peguys Cahiers de la guinzaine, which would be a source of spiritual light for literate Frenchmen. In this, he was no different from hundreds of other young Parisian idealists, for a plethora of ephemeral reviews and journals, concerned with the state of society, made hasty entrances and just as hurried exits from the Paris literary scene.

Mounier's experience, in this respect, turned out differently. With friends, he established Esprit, which first appeared in october of 1932 and lasted, unlike any other new review of the 1930's, past World War 11 , suspending publication only after his death in 1950.166 During its life, and the life of its director, Esprit's pages were filled with earnest critiques of French society and church dogma and hopeful notes on philosophical constructs.

When the Second World War broke out, Mounier immediately saw the cause of France!s ignominious defeat. It lay with the class that had always been the least responsible in French society, the class with the most meaningless, most disruptive values. The bourgeoisie, though not the whole nation, had been numerous enough to paralyze the reflexes of the entire nation. 167 For one thing, the bourgeoisie were

165 pierce, Political Thought, 32.

166 Ibid.. 33 .

167 Emmanuel Mounier, "Letter From France," Commonweal, 32, (october 25, 1940), 9 . 
never in favor of war; they saw that "whoever won, capitalism would be the victim... That is the dead weight which depressed France's energy to resist."1168

Mounier's two biographers agree that he was a gentle and peaceful man, not particularly adventurous, concerned almost solely with questions of philosophy. This serenity did not, however, prevent him from entering actively into the resistance during the war. (Having lost an eye at the age of thirteen, he had been eligible only for the services Auxiliares of the army, which he joined. He was captured and held prisoner until July of 1940, when he was released and demobilized.) The Vichy regime banned Esprit, so Mounier organized a clandestine study group in Lyon, where he was living at the time. According to Pierce, he was connected with the famous Combat group, which was so important during the resistance. 169 In fact, in January of 1942, he and several Combat leaders were jailed. The year he spent in prison probably shortened his life. After his release, he continued to be active in the resistance, mainly by contributing to its journals, such as La France intérieure and Les Cahiers politiques, the organ of the Comité Genéral d'Etudes, the main group charged with mapping France's post-war future. At the war's end, Mounier assessed the whole saga. He remained convinced that the bourgeoisie had betrayed France

$$
\begin{aligned}
& 168 \text { lbid. } \\
& 169 \text { lbid., } 40-41 .
\end{aligned}
$$


at llunich and performed dishonorably at Vichy. 170 The urgcoisie had been the "directing class" of France since ac eighteenth century, but now, in its disgrace, it was through. 171 It had been "massively Petainist."172 "And there is something almost funny about that. For never was it given to the bourgeoisie to hear such bitter home truths about its own selfishness - and from a bourgeois at that as when it listened to the Marshal's speeches."173

The consuming interest of Mounier's intellectual career was to create the conditions of freedom, justice, unity, and morality, under which all men were entitled to live. To this end he constructed, or reconstructed (because others had referred to it before him) the concept he called personalism. More than an attitude and less than a system, as Pierce says, personalism is not truly a philosophy, as Mounier claimed. 174 Neither Mounier nor the body of ideas he called personalism were particularly politically oriented, although he believed that personalism could aid men in making political choices. That he thought this was a consequence of a fundamental characteristic of his outlook,

170 Emmanuel Mounier, "The Structures of Liberation," Commonweal, 42, (May 18, 1945), 112.

\section{1 lbid.}

172 Emmanuel Mounier, "France in the Catacombs," Commonweal, 42, (Hay 11, 1945), 85.

$$
\begin{aligned}
& 173 \text { lbid. } \\
& 174 \text { bid., } 50 .
\end{aligned}
$$


for he was basically a Christian moralist who made the classic division of social acts - good and evil. Yet he believed that political values could not be derived from a single philosophical system, especially not his own. This was largely because personalism contained unforseeableness as an operative principle, and also because his outlook was grounded in contrasts and dilemmas. 175

Mounier examined Marxism for a number of reasons. One of these was that Marxism had criticized the same institutions which he found repulsive - Capitalism, the bourgeoisie, and parliamentary democracy. Together they formed what he scornfully referred to as "1"le desordre etabli;176 modern society had become the negation of Christian principles to such a degree that its failings could be cited in scientific terms :

First axiom: The bourgeois is the man who has lost the sense of Existence: 177 Second axiom: The bourgeois is the man who has lost. [the idea of] Love. 178

Bourgeois society thus made a cult of mediocrity and, in so doing, denied or forgot the elements of history and religion which had brought him to the comfort he enjoyed, most notably, the Cross. 179 He admired Catholic socialists

175 lbid.

176 Mounier, 0euvres, $1,375-406$.

177 lbid., 390 .

178 1bid., 391 .

179 lbid., 392. 
like Leon Bloy and Peguy who had attacked the bourgeois earlier on these same grounds. 180

As Pierce rightly comments, Mounier's attack on democracy was based on his distaste for existing practices; he was still an admirer of the ideal.181 capitalism, on the other hand, was fundamental to the established disorder. 182 For Mounier, however, Christianity had no connection with the established disorder. Instead, he felt that the church transcended history and society. It could make errors and had done so historically, but it could only be indifferent to political forms, democratic or authoritarian. By saying this, he was trying to make clear and valid the separation of religion and politics.183 In making that separation, Mounier hoped to be capable of infusing personalism with the revolutionary spirit which resided in Marx.

It is important to note here that Mounier's concept of Marxism was, like that of many French intellectuals, derived from the "vulgar" pre-1848 corpus of Marx's writings

180 lbid., 393.

181 pierce, Political Thought, 51.

182 see "La double fonction de la proprieté," 441-452, in Oeuvres, 1 .

183 see especially "Christianisme et Communisme" and "Le communisme devant nous" in Deuvres, IV. An interesting topic in this regard would be Mounier's influence on communist intellectuals, particularly in eastern Europe and Latin America, where the influence of the church is undiminished. Certainly, Roger Garaudy, a leading theoretician of the French party has taken up the theme in his From Anethema to Dialogue (New York: Herder and Herder, 1963). 
which spoke with such fervor of the liberation of mankind from alienation. 184 The later, grimmer Marx; which dwelled on class struggle, surplus value, historical materialism, was, as Herbert Luethy suggested, ignored or never known by these people. In Mounier's case, according to Pierce, he was aware of Marx the economist, but detected in the Marxist legacy, a duality, each part of which was mutually exclusive of the other. 185 If the French Communist Party could live by the tenets of the later Marx, he, Mounier, could be informed by the earlier, the revolutionary, the humanistic Marx.

This helps to explain why Mounier never held Soviet communism in any high regard.

Certainly. Mounier made it clear where he felt personalism could learn from Marxism. In Be Not Afraid, he wrote that personalism "lags behind Marxism in its philosophic analysis of homo faber, its social and economic analysis of the contemporary world and its experience of action.11186 Like Marx, Mounier endorsed the machine age and admired Marx's analysis of the function of the machine in industrial society. 187

184pierce, Political Thought, 77.

185 1bid., 77-78.

186 Emmanuel Mounier, Be Not Afraid (New York: Sheed and Ward, 1962), 172 .

187 see "La machine en accusation," Deuvres, IV. Also, in this connection, Michael Harrington has written in "Mounier: Tragic Optimist," in Commonweal, LX, (August 20, 1954), 489-490, that both Marx and Mounier were overly. optimistic about the machine and the industrial age: 
Mounier felt that personalism "sheds a broader light on inferiority and transcendence than the most broadly based Marxism."1188 The reciprocity of ideas and methods that he thought Harxism and personalism could enjoy would aid in the reconstruction of modern society. The new world would therefore gain the benefits of a social construction that was characterized by the fulfillment of the individual's self (through personalism), his integration into the truly industrial state (through Marxism), and morality and spirituality (through Christianity).

This was all part of Mounier's desire to build a culture and civilization in France which would be the embodiment of Christian principles, and at the same time the fulfillment of the individual.189 That, of course, bourgeois society could never succeed in attaining, for it was the very thing that inhibited the realization of personal fulfillment. It had cultivated reason, science, and technology in the pursuit of the new society of capital and industry, and had found instead alienation, anxiety, mediocrity, and spiritual dullness. To Mounier it seemed that the middle class had come a long way for utopia only to end by immersing European

". - What is left out of Mounier and Marx is the possible absolutism of the machine. Even in a society in which production is regulated in the most utopian fashion, the very processes of industry are a brutalizing factor." (p. 489)

188 Mounier, Be Not Afraid, 172.

189 see Donald Wolf, "Emmanuel Mounier: A Catholic of the Left," Review of Politics, 22, (July, 1960), 324-344, for an accurate and ITluminating synthesis of Mounier's thought. 
man in a nightmare. The solution lay in reasserting the spiritual vitality of the human being and putting it to work in the construction of a new and dynamic Christian society in which the potentials of industrial democracy were harnessed to bring equality and fulfillment to all men. 


\section{JEAN-PAUL SARTRE: THE EXISTENTIALIST'S SEARCH FOR PERSONAL FREEDOM IN \\ THE TWENTIETH CENTURY}

\section{As alienation from all social constructs became, in} this century, a pervasive theme of intellectual activity, the burden of cultural despair became not how to deal with modern life in economic, artistic, or religious terms, but only as a single individual at a moment in history. For this reason, existentialism, a trend in modern European philosophy, that concerned itself with the individual, had deep roots in the European intel lectual tradition, and was the movement that most persistently returned to the concerns of cultural despair, became the most important social philosophy of the twentieth century.

No existentialist has been more active in the quest for the amelioration of the individual's condition in the modern world than Jean-Paul Sartre. An enemy of the limitation of freedom, conformity, and systematization of life that he feels are the hallmarks of bourgeois society, Sartre has tested his ideas in nearly every form of intellectual endeavor including fiction, drama, sociology, psychology, political theory, and the philosophy of history. One concern, to which he has often returned, is the value of Marxism as a tool of 
history and therefore social improvement. This has led him, like Mounier, to attempt to amalgamate Marxism with his own philosophy. But he has never given into the urge to construct a utopia or search for a panacea. He has instead chosen to examine all possible avenues with a high degree of critical responsibility. As a result, he has had a continuous and monumental struggle with Marxism. The following study focuses on this struggle, since it is a microcosm of the existentialist's search for the solution of the modern predicament.

Jean-Paul Sartre was born in Paris in 1905. His father died when Sartre was quite young. 190 His mother remarried and the family moved to the coastal town of La Rochelle. He graduated from the local high school as an average student. Sartre continued his studies in Paris, entering the field of philosophy. He graduated, entered the army for sixteen months, pursued his studies in Germany under Husserl, then taught high school in Le Havre and, later, Paris. In 1939, he again entered military service, was captured by the Germans, was released from prison camp because of ill health, and returned to paris to work in the Resistance.

190 See Jean-Paul Sciltre, The lords (New York: George Braziller, 1964), Norman N. Greene, Jean-Paul Sartre (Ann Arbor: University of Michigan Press, 1960), and Simone de Beauvoir. The Prime of Life, (Cleveland: World Publishing Company, 1960), for details of Sartre's youth and early manhood. 
In 1938, Sartre had published his first novel, Nausea, which was an immediate success. At the same time it created a scandal because of the new and disquieting ideas it contained, which, of course, were the rudiments of his existentialism. Sartre also published his studies in psychological theory and initiateditis career as a literary critic. This corpus of existential thought preceded by several years his major philosophical tract, Being and Nothingness (1943), and though his principal dramatic works, The Flies and No Exit also appeared during the war, it seems clear that the events of the war were not, as some critics think, the original catalysts for his ideas. 191

Sartre's introduction to Marxism had occurred during his university days. In 1925, when he was twenty, there was no chair of Marxism at the University and even communist students avoided mentioning Marx. "The horror of the dialectic," he recounts, "was such that Hegel was unknown to us." 192 One read Marx only so as to be able to refute him. At about that time, Sartre read the German Ideology and Capital. While they seemed to have no immediate effect on his mind, the reality of Marxism itself did change for him. He realized, for the first time,

the heavy presence on my horizon of the masses of workers, an enormous, somber body which lived Marxism, which practiced $i t$, and which at a distance exercised an

$191_{G}$ reene, Sartre, 3.

192 Jean-Paul Sartre, Search for a Method (New York: Alfred A. Knopf, 1963), i7. 
irresistible attraction on petit bourgeois intellectuals.193

Sartre and his fellow students had fallen into the worn structures of petit bourgeois thought, but, as he notes, the war, occupation, and resistance were to shatter those edifices. 194 And it was during those hazardous war years that they wanted to fight side by side with the working class. "We finally understood that the concrete is history and dialectical action."1195

Simone de Beauvoir, the novelist and Sartre's sometime mistress, has retold in her memoirs the unstructured conflicts of political philosophies which seemed to rage in the mind of the young Sartre:

Sartre built his theories, fundamentally, upon certain positions which we both adhered to with some passion. Our love of freedom, our opposition to the established order of things, our individualism, and our respect for the working classes - all there brought us close to an anarchist position. But to be quite frank, our incoherence defied any sort of label. We were anti-capitalist, yet not Marxists. . . Though our interpretation of men and the universe was strictly materialistic, we despised science and technology. Sartre was not bothered by these inconsistencies, and refused so much as to formulate thern. . . He himself skipped from one conviction to the next wi thout rhyme or reason. 196

Later, however, Sartre's views began to coalesce.

193 Ibid., 18.

194 ibid.,

195 lbid., $20-21$.

196 de Beauvoir. Prime of Life, 39. 
$\therefore s$ a writer, he regarded the artist as a stranger in every society.197 The Soviet Union, the supposed epitome of the rarxist experiment, was to him merely a society of engineers without any cultural values. Moreover, the nightmare of soviet $1 \mathrm{ife}$ for the creative and independent-minded in the period of the thirties was not lost on him. At the same time, and especially during his tenure at the lycé of Le Havre, Sartre began to show his distaste for the middle class - to which, of course, he belonged; a fact which he never denied. He began passionately to hate the bourgeois "analytical" intellectuals. They were phrasemakers who spoke of democracy, equality and other shibboleths.198. As a natter of fact, it was at this time that he began frequenting the poorer sections of town, rubbing shoulders with the rorkers. 199

With the publication of Nausea in 1938, Sartre established himself, with Albert Camus, as the intellectual hope of France. 200

197 Jean-Paul Sartre, What is Literature? (New York:

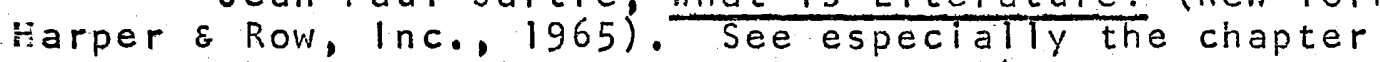
entitled "Situation of the Writer in 1947." In this work, writen at a date later than the point at which we find nim in the narrative above, he noted that the writer had to search on his own for the literary values which could inform his particular work and at the same time aid in the rethinking of society. He had to escape his bourgeois sensibilities and avoid the pitfalls of the contradictions of Marxism.

198wilfrid Desan. The Marxism of Jean-Paul Sartre

(Garden City, New York: Doubleday, 1965), 2-3.

199 lbid.

200 Park, Culture of France, 18. 
As the saga of the Resistance opened, the world of French

letters had charged them with the responsibility of representing wartime France's literature. The combination emerged from World War 11 in tact and in charge, as it were, of the new wave of post-war literature. 201 In their roles as "mentors for their time," they wrote essays, philosophical studies, articles, and novels, all highly didactic in tone. 202 To Sartre and Camus had fallen the profound burden of delineating the scope and direction of the French mind. The task of dealing with Marxism was now inevitable.

The legacy of the war and resistance was, for sartre, decisive. His notions of guilt and responsibility had, during that time, matured.203 Moreover, the tragic experience of the forties had ultimately convinced him and many of his colleagues that historical materialism was the only valid interpretation of the past.204 At the same time; he had reached the conclusion that existentialism provided the only concrete approach to reality.205 He now felt that

201 lbid.

202 in sartre's case, these works included such plays as No Exit, 1946, (though actually performed during the war as early as 1945). The Flies (also published and performed earlier in France-1943). The Respectful Prostitute, 1948 , and Dirty Hands, 1948. His novels of this period included The Reprieve, 1945. The Age of Reason, 1945, and Troubled Sleep.

203 caute, Communism, 248. 204 lbid. $2051 \mathrm{bid}$. 
man exists first and defines himself afterward. The conflict between existentialism and modern life had begun to surface in his mind. And it was because of this conflict, that at this point, his struggle with Marxism began to take shape. Sartre's ambivalence about Marxism can be seen in the play "The Flies." There his disillusionment with structured reality - rationale imparted by state or political or social system - is evident. Orestes, the protagonist, is completely self-centered: he murders his mother Clytemnestra (the play is based on the Medea cycle,) not with the motive of revenging his father's death, nor of reestablishing justice, but as an act of personal definition. He thus consciously defies Zeus, who represents the system.

1 have done my deed. . . and that deed

was good. I shall bear it on my shoulders

as a carrier at a ferry carries the traveler

to the farther bank. . . The heavier

it is to carry the better pleased I shall

be; for that burden is my freedom. 206

orestes' existential decision, an exaltation of the individual at the expense of the system, is Sartre's initial blow in a definite and persistent effort by him to ameliorate the individual's condition in his relation to middle class social constructs. "I am my freedom," the single man is the ultimate explicator and master of his own existence, Sartre's hero says.207

206 Jean-Paul Sartre, "The Flies," in No Exit and Other Plays (New York: Vintage Books, 1955), 108. 207 lbid., 111. 
His reverence for the individuali notwithstanding, Sartre was still attracted by Marxist ideology. This ambivalence was dramatically revealed in 1952, when the world of letters was treated to the spectacle of France's most prestigious writers, Camus and Sartre, flailing each other in print, on the pages of Sartre's periodical, Les temps modernes. The feud had started, ostensibly, over an acid review of Camus' essay L'homme revolte, written by Francis Jeanson, a protege of Sartre's. The real issue, however, was Camus' and Sartre's divergent views on Marxism. Camus had fired off a clever, but uncommonly violent reply to the review, which appeared in the pages of Les temps modernes. The main thrust of Camus' statement was aimed not at Jeanson, his original attacker, but at Sartre. Sartre, of course, immediately published his reply. Aside from the more personal matters of literary jealousy, the exchange brought to light the discrepancy between Camus' bold repudiation of Marxism and Sartre!s less well defined attitude toward it. In fact, Sartre's position smacked unmistakably of temporizing and unsureness, an intellectually honest, a scholarly unsureness, but nevertheless, unsureñess.

In speaking to one of the issues Camus had raised in his letter, that of the just revealed soviet concentration camps, Sartre displayed his contempt for the modern condition in the bourgeois democracy as well as in the totalitarian state. Somewhat wearily he wrote, "the Iron curtain is only a mirror, where each half of the world reflects the other. 
Each turn of the screw here corresponds to a twist there, and both here and there, to finish, we are both the screwers and the screwed."1208 And, still, in the same essay, he could speak of Marxism's "profound truth."209 Unlike Camus, who could not disassociate Marx from Stalin's enormities, Sartre was struggling to make the necessary division. That was perhaps the crux of his problem.

However tortured the evolution of Sartre's sociopolitical conscience or consciousness has been, he has remained the "most perceptive and morally responsible of the French philosopher-writers to have wrestled with the problem of communism."210 That is because, for sartre, Marxism has been a unique and formidable obstacle, an intellectual Everest which, when conquered, may be discovered to be the end of the quest, or the last barrier. One critic has said it is the primary impediment in the path of the completion of Sartre's major project, which is one of "negation, negation of all limitation of freedom, all hampering of man's free movement, all frustration and alienation." 211 The consuming interest of his intellectual

208 Sartre's reply to Camus is collected in Sartre's Situations (New York: Gaorge Braziller, 1965). It was originally published in Les Temps Modernes in the same issue in which Camus' letter was printed, the August, 1952 issue. The quotation is from $p .86$ of situations.

$$
\begin{aligned}
& 209 \text { lbid, } 88 . \\
& 210 \text { Caute, Communism, } 247 . \\
& 211 \text { Desan, Marxism of Sartre, } 2 \text {. }
\end{aligned}
$$


career has thus been the revolt against repetition, organization, and conditioning which crushes creativity. 212

Thus, in Search for a Hethod, a book expanded from an article entitled "the Situation of Existentialism in 1957," which he wrote for a Polish magazine, and included as the first part of his second major philosophical treatise, critique of Dialectical Reason, Sartre made his most incisive statement on Marxism, basing his conclusions, he said, on one fundamental contradiction in Marxism, "that of existence and knowledge."1213 Calling truth, in the Hegelian sense, totalization recognized as History and historical Truth214 Sartre wrote, of our time which we cannot go beyond
and $\dot{0}$. I hold the ideology of existence
and its "comprehensive" method to be an
enclave inside Marxism which simultaneously
engenders and rejects it. 215 In a notably perceptive introduction to a collection of essays treating of Marxism and existentialism, George Novack comments that Sartre's most extensive arguments against Marxism appeared in a 1946 piece entitled Materialism and Revolution, 216 but the foregoing statement seems to capture all of Sartre's ambivalence toward Marxism, to

212 lbid., 1 .

213 sartre, Search for a Method, $x \times x \| 11-x \times x \mid V$. 214 bid., $x \times x 1 \mathrm{~V}$

$2151 \mathrm{bid}$

216 George Novack, ed., Existentialism Versus Marxism (New York: Delta Books, 196 ). 19. 
present his most unequivocal, courageous, and prescient view of its value and relevance, and its relationship to his own theory of existence. In fact, as Novack notes, in Search for a Method, Sartre virtually dissolves Marxism into existentialism, (existentialism "simultaneously engenders and rejects it"). 217 But, that is not to say that he amalgamates them, as Adam Schaff, the Polish Marxist philosopher, has claimed in "a Philosophy of Man."1218 Rather (and how difficult for a Marxist to recognize it how traumatic if he does,) Sartre turns the dialectic against Marx.

As soon as there will exist for everyone a margin of real freedom, Marxismwill have outlived its span; a philosophy of freedom will take its place. 219

Thus, Sartre does to Marx what Marx used to do to his own antecedents. He makes scientific socialism a great, but transient, social system containing the seed of its own destruction, which waits to be activated by the inevitable turn of events, events to which Marxism will no longer be relevant, in the inexorable historical process. To Sartre, existentialism is an ideology, a "parasitical system" living "on the margin of knowledge. . . into

\section{1bid., 23.}

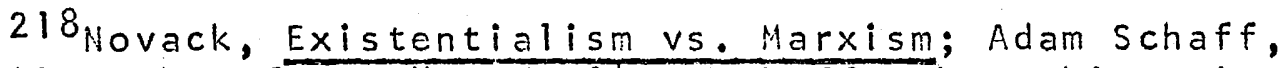
"A Philosophy of Man,"297-314. Schaff makes this point the theme of his entire essay.

$$
219 \text { Sartre, Search For a Method, } 34 .
$$


which. - it seeks to be integrated."220 Thus, by drawing Hegel over to the side of existentialism,22l Marxism is robbed of its dynamic; the dynamic is infused into existentialism, which becomes, then, the inheritor of the mantle of "responsibility" to the masses, which Marxism formerly wore. Existentialism superannuates and supersedes Marxism because it has the new dimension of considering individual freedom. After bourgeois society has been reorganized - goods and capital properly distributed - the "margin of real freedom" is thus initiated, which, to be preserved, has got to be illuminated and secured by the new "ideology" of existentialism. 222 Marxism, then, for sartre, only brings the individual to the total amelioration of his condition in society when, after subsuming his identity and freedom in that of the masses, it finally fulfills the limit of its vision, its mission, and, in so doing, reintroduces the possibility of individual freedom. 223

\section{0 lbid., 8.}

221 lbid., 19, ff. Sartre says, for Hegel "existences are enmeshed in the history which they make and which, as a concrete universality, judges and transcends them." Thorough critiques of Hegel, for the interested reader, are Herbert Marcuse's Reason and Revolution, (Boston: Beacon Books, 1954).

\section{2 lbid., $x \times x \mid v$.}

223 See Karl Marx and Friedrich Engels, the Communist Manifesto (New York, 1964). It would be, at best, foolhardy to attempt to trace Sartre's concept of Marxism's promise in a footnote, but the reader is directed to one of the most salient works on the subject. The Manifesto yields the crucial chapter 1 , 57-79 and the open-ended statement on 95, "in place of bourgeois society, with its classes and class antagonisms, we shall have an association in which the free development of each is the condition for the free development of all." (italics mine.) 


\section{CONCLUSION: A HODERN THEME}

There is a story, perhaps apocryphal, that once while Metternich, the great defender of the European status quo, was strolling in his garden an eclipse of the sun occurred. He, who became disconcerted by any change in the political order, was so upset by this deviation in the natural order that he ran indoors, climbed into bed, and was ill. Not much effort then is required to imagine the impact on the European mind of the rapidly changing world of the late nineteenth and early twentieth centuries. Used to cultural traditions that had not changed substantially in four centuries, Europe was now bearing witness to their almost total destruction in less than two.

In this discussion, we have attempted to trace the path of the syndrome that characterized the reaction of the intellectual class to that destruction. In beginning with Proudhon, the nineteenth century revolutionary, we observed a man whose sensibilities were among the first in Europe to be outraged by the new liberal economic and political constructs of the nineteenth century. Having traced to these constructs the causes of the discrepancies in French life, Proudhon violently attacked their guardian and chief 
benefactor, the middle class. His solution was one that was to recur again and again in the critique of bourgeois denocracy. He demanded a general leveling of society, politically, economically, socially, in the hope that society would thereby hang together in harmony and security.

In that and other senses, Proudhon was rooted fundamentally in the classical economic tradition of Smith and Ricardo (although, as we have said, he was distrustful of laissez faire) who believed in the basic harmony of interests of all men in society, and in the utopian tradition of st. Simon and Fourier who believed in the ability of man to achieve the total integration of himself in a social, political, and economic context. Like Bentham, moreover, he believed, or professed to believe, in the utility as the criterion for social and political institutions.

He noted that bourgeois society, as it existed in France, did not conform to those standards that it had, itself, laid down. It was a hypocritical society in that it claimed the harmony of interests of men in economic life, but did not, in fact, practice it. Some men were noticeably wealthier than others; some men exploited others through unfair and unnatural economic devices, such as property and interest. And because of these economic inequalities, the integration of men into the political and social comity (which for him and the utopians was almost a secular version of the res Qublica christiana) was impossible. This hypocrisy of the middle class was thus an injustice it perpetrated on the rest. 
of society. Justice thus became the theme and consuming interest of Proudhon's career.

The young Marx was impressed with Proudhon's critique of industrial and commercial society and so was the anarchist Bakunin. In Proudhon, they thought they had discovered a revolutionary hero. Marx, of course, found out differently, and in the Poverty of Philosophy revealed it for the socialist world to see. Instead of revolutionary toughness, Marx detected in Proudhon Christian moralism. Instead of dialectical awareness, a view that existed essentially out of history.

Yet despite Marx's vigorous attack, Proudhon remained, throughout the nineteenth century, a figure of tremendous revolutionary appeal, perhaps because his attack on bourgeois society was based fundamentally on the simple human instincts for justice and security, which for many men in those times appeared to be revolutionary principles.

If the revolutionary looked Janus-like back to his intellectual roots and at the same time ahead to a future of equality, justice, and unity beyond modern constructs, the artist often turned his back completely on modernity. Thomas Stearns Eliot was such an artist. In "Tradition and the Individual Talent," the essay in which he recorded his critical standards, Eliot said the artist must nourish his creative genius in the traditions of the past, that any contribution to the culture must be in concert with those traditions. 
But he saw increasingly in the modern world, the estrangement of the culture from those very traditions which were to keep it viable, enrich it. He saw the total society as being gradually weakened by the norms of modern existence. The protagonist of "The Love Song of J. Alfred Prufrock," was his model of the paralysis that seized the bourgeois. In his greatest poem, "The Wasteland," he warned of the sterility of the culture in all its aspects, and contrasted it with images and allusions from classical culture. Modern man was sexually as well as intellectually and emotionally paralyzed, he said. Modern society was culturally and socially dislocated. Mediocrity and banality had replaced excellence and good taste as aesthetic norms; once respected social institutions had decayed to the point that they were ludicrous. In "The Wasteland" and in other poems, he depicted Jews as being at the heart of modern disorders.

To publicize his views and similar ones of his contemporaries, Eliot founded and edited a literary review, Criterion, in which he hoped to alert the intellectual community to the problems of modern, culture. In its seventeen years of existence before the outbreak of war in 1939. Criterion served as a forum for cultural critics such as Charles Maurras, Bernard Shaw, G. K. Chesterton, and Ezra Pound.

The literary artist might easily defend his cultural heritage, but in trying to salvage his confession from the modern world, the Catholic would have a more difficult 
problem. In a world which saw the universe as man-centered, the cosmically oriented Catholic had to fight a hard bettle to survive with his beliefs.

Emmanuel Mounier succeeded in creating an amalgam of secular ideals and his Christianity. Believing the bourgeoisie to have created a society in which man had gotten more and more estranged from the ethic and morality of Christianity, and to have lost the idea of love, as well as of existence itself, all in the quest for capital, Mounier called for the reorganization of society so that the bourgeoisie would be excluded from its role of cultural arbiter. Descended from the vitalists of the late nineteenth and early twentieth centuries who believed in the ability of the human spirit to create the conditions of its own well-being, Mounier founded the personalist movement, and attempted to suffuse it with the revolutionary spirit of Marxism in the hope that, held together by christian principles, this revolutionary humanism would achieve, in effect, the radical conversion of society and lead to the total fulfillment in the world of the Christian person.

The tradition of existentialism in Europe is a microcosm of the struggle with the despair engendered by bourgeois society. Thrown back on themselves by the spatial limitations of the modern urban environment, restricted in political action by the repressive tendencels of bourgeois democracy, and disoriented by hollow and meaningless moral, ethical and aesthetic standards, the existentialists have withdrawn 
into their own minds and created systems with which the single individual can live in or combat modern life.

Jean-Paul Sartre's existential philosophy was formed in this crucible. Contemptuous of bourgeois conventions from his youth, Sartre's philosophical convictions matured and hardened into an atheistic and dialectical system based on the phenomenology of Hegel and Husserl. Early in his career Sartre turned to Marx for support and went so far as to attempt to incorporate Marxism with existentialism, Whereas Mounier's alliance of Christianity and Marxism was often tenuous, Sartre has felt that its promise of the relief of the individual from alienation, justified an attempt to form a unity of the two apparently opposed systems.

It has not been an easy task. Plagued by the criticisms of his fellow philosophers, particularly Albert Camus, and by the inconsistencies of Marxism's modern practicioners, and of Marxism itself, Sartre has from time to time been faced with a crisis of the mind. But since his intellectual quest is for nothing less than the grail of total personal freedom in the modern world, he has never stopped his relentless examination and criticism of his beliefs and of the modern context.

The tapestry of European history in these two centuries, the nineteenth and the twentieth, is rich and heavy. The intellectual historian, in trying to plumb the mind of the age, hardly knows which thread of the magnificent embroidery 
to pick up first. Cultural despair is only one of many, but the eye of the historian is attracted to its many convolutions. And even if he follows its course assiduously, in the end he can only guess at its numerous possible conclusions. For the impact of modern life on the minds of the cultural traditions of European thought has not yet played out. But when final assessments are possible, no better expression of cultural despair will be found than this one that appears on the closing pages of Huysmans Against the Grain, where Des Esseintes, the hero, contemplated his return, from selfimposed exile, to modern society.

Of a surety, no haven of refuge was open to him, no shore of safety left. What was to become of him -in Paris yonder, where he had neither relatives nor friends? No tie bound him any more to the Faubourg Saint-Germain that was now quavering in its dotage, scaling away in a dust of desuetude, lying derelict - a worn-out, empty hull! - amid a new society! And what point of contact could there be between him and that bourgeois class that had little by little climbed to the top, taking advantage of every disaster to fill its coffers, stirring up every kind of catastrophe to make its crimes and thefts pass muster?

After the aristocracy of birth, it was now the turn of the aristocracy of money; it was the Caliphate of the countinghouse, the despotism of the Rue du sentier, the tyranny of commerce with its narrow-minded, venal ideas, its ostentatious and rascally instincts. in painting, it was a de luge of effeminate futilities;

in literature, a welter of insipid style and spiritless ideas. What was a-lacking was common honesty in the business gambler, common honour in the freebooter who hunted for a dowry for his son while refusing to pay his daughter's, common chastity in the voltairean who accused the clergy of incontinence while he was off himself to sniff, like a dull fool and a 
hypocrite, pretending to be the rake he was not, in disorderly dens of pleasure, at the greasy water in toilet vessels and the hot, acrid effluvium of dirty petticoats.

It was the vast, foul abanio of America transported to our Continent; it was, in a word, the limitless, unfathomable, incommensurable firmament of blackguardism of the financier and the self-made man, beaming down, like a despicable sun, on the idolatrous city that grovelled on its belly, hymning vile songs of praise befqre the impious tabernacle of

Commerce.

$224 \mathrm{~J}$. K. Huysmans, Against the Grain (New York: Hartsdale House, $19511, \overline{336-338 .}$ 
B I BLIOGRAPHY

Books

Adams, Henry. The Education of Henry Adams. Boston: Houghton Mifflin Co., 1918.

Andreach, Robert J. Studies in Structure. New York: Fordham University Press, 1964.

Arendt, Hannah. The origins of Totalitarianism. Cleveland: The World Publishing Company, 1958.

Aron, Raymond. L'opium des intellectuels. Paris: CalmannLevy, 1955.

Baudelaire, Charles. Flowers of Evil. New York: Peter Pauper Press, 1950.

Beauvoir, Simon de. The Prime of Life. Cleveland: World Publishing Company, 1960. 6 .

Bergsten, Staffan. Time and Eternity. Sweden: Berlingska Boktryckeriet Lund, 1960.

Berlin, Isaiah. Karl Marx. New York: Oxford University Press, 1963.

Black, Eugene C. (ed). Posture of Europe, 1815-1940. Homestead, 111 inois Dorsey Press, 1964.

Braybrooke, Neville. T. S. Eliot: A Symposium for his Seventieth Birthday. London: Rupert hiprovis, 1958.

Brogan, D. W., The Development of Modern France. Vol. 2 . New York: Harper Torchbooks, 1966.

Brown, Norman 0. Love's Body. New York: Random House, 1966.

Carr, E. H. Michael Bakunin. London: MacMillan E Co., Ltd., $19 \overline{37 .}$

Caute, David. Communism and the French Intellectuals. New York: The MacMilian Company, 1964. 
Cole, G. D. H. Socialist Thought. London: MacMillan $E$ Co., Ltd., 1954.

Curtius; E. Robert. The Civilization of France. Hew York: Vintage Books, 1962 .

Dangerfield, George. The Strange Death of Liberal England. New York: Capricorn Books, 1961.

Desan, Wilfrid. The Marxism of Jean Paul Sartre. Garden City, New York: Double and Company, 1965.

- The Tracic Finalé. Cambridge, Mass.: Harvard University press, 1954 .

Dostoyevsky, Fyodor. The Brothers Karamazov. New York:

Dell publishing Company, Inc., 1956.

Eliot, T.S. After Strange Gods. New York: Harcourt, Brace \& company. 1934.

- The Complete Poems and Plays. New York:

Harcourt, Brace and World Inc., 1952.

Ltd.. ? Points of View. London: Faber and Faber,

. Selected Essays. Hew York: Harcourt, Brace

Freud, Sigmund. Civilization and its Discontents. New York:

Liveright Publishing Company, 1950.

- Group Psychology and the Analys is of the Ego.

New York: Bantam Books, 1960 .

- The Interpretation of Dreams. New York:

Avon Books, 1965 .

George, A. G., and Rajan, B. T. S. Eliot, His Mind and Art. India: Asia Publishing House, 1962 .

Gide, André. The Immoralist. New York: Vintage Books, 1958.

Gide, André, and Valery, Paul. Correspondence. Paris: Gallimard, 1955.

Grana, Cesare. Modernity and its Discontents. New York: Harper Torchibooks, 1966 .

Greene, Norman N. Jean-Paul Sartre. Ann Arbor: University of Michigan Press, 1960. 
Halasz, Micholas. Captain Dreyfus: The Story of a Mass Hysteria. New York: Grove Press, Inc., 1955.

Hamilton, Edith. Mythology. Hew York: The New American Library, 1940.

Harper, Ralph. Hostalgia. Cleveland: Hestern Reserve University Press, 1966.

Headings, Philip R. T.S. Eliot. New York: Twayne Publishers, Inc. 1964.

Holderi, Alano. Three Voyagers in Search of Europe. Philadelphia: University of Pennsylvania Press, 1966.

Houghton, Walter E. The Victorian Frame of Mind. New Haven: Yale University Press, 1966.

Hughes, H. Stuart. Consciousness and Society. New York: Vintage Books, 1958 .

Huizinga, Johan. The llaning of the Middle Ages. Garden city, New York: Doubleday Anchor Books, 1954.

Huysmans, J. K. Against the Grain. New York: Hartsdale House, 1931.

- La Cathedrale. Paris: Libraire Plon, 1908.

Hyman, Stanley E. The Armed Vision. New York: Alfred A. Knopf, 1955.

Jaurès, Jean (ed). Histoire Socialiste. Paris: Jules Rouff Publications, ?.

Johnston, John H. English Poetry of the First World War. Princeton, New Jersey: Princeton University Press, 1964.

Jones, Genesius. Approaches to the Purpose. New York: Barnes \& Noble,-1nc.,-19-65.

Joyce, James: A Portrait of the Artist as a Young Man.

Kafka, Franz. The Trial. New York: Modern Library, 1956.

Kriegel, Annie. Aux origines du communisme francaise.

Paris: Mouton \& Co., 1964.

Leite, Nathan. On the Game of Polltics in France. Stanford, California: Stanford University Press, 1959 . 
Lu, Fei-pai. T.5. Ellot: The dialectical structure of in Theory of Poetry. Chicago: The University of Chicago Press, 1960.

Lubac, lienri de, S. J. The lirama of Atheist Humanism. Cleveland: The liorid Fublishing Conpany, isj.

Sheed and Proudhon, the un-Harxian Socialist. Hew York:

Lucy, sean. T. S. Eliot and the ldea of Tradition. London: Cohen \& Test, 1960.

Luethy, Herbert. France Against Herself. New York: Meridian Books, 1957.

Hanue 1, Frank. The Prophets of Paris. Hew York: Harper Torchbooks, T965.

Marcuse, Herbert. Eros and Civilization. Boston: The Beacon Press, 955 .

Marx, Karl. The 18 tin Brumaire of Louis Bonaparte. Hew York: International publishers, 1963.

Language Press, T950.

McGreevy, Thomas. Thomas Stearns Eliot. London: Chat and Windus, $19 \overline{31 .}$

Mead, Sidney E. The Lively Experiment. New York: Harper \& Row, Publishers, 1963.

Miller, Hilton L. Nostalgia: A Psychoanalytic Study of Marcel Proust. Boston: Houghton Miffin, 1956 .

Mounier, Emmanuel. Oeuvres. Paris: Editions du Sevil, 1962.

- Personalism. London: Routledge E Kegan Paul,

Musgrove, S. T.S. Eliot and llalt lhitman. Willington, New Zealand: liew Zealand UnTversity press, 1952.

Namier; Sir Lewis. 1848: The Revolution of the Intellectuals. Garden City, New York: Anchor Books, 1964.

New Testament, King James Version. Philadelphia: National Putising Company, 1941 .

Hietzsche, Friedrich. Joyful llisdom. New York: Frederick Ungar publishing co., 19ut. 
Hovack, George (ed.). Existentialism vs. Marxism. Hew York: Delta Books, 1965.

Odajnyk, Valter. Marxism and Existentialism. Garden City, ivell York: Anchor Books, Tous.

Ortega y Gasset, Jose. The Revolt of the Hassas. Hew York: H. Horton and company, 1937.

Park, Julian. The Culture of rrance in Our Time. Ithaca, New York: Cornell University Press, 1954.

Pierce, Roy. Contemporary French Political Thought. London: $0 x$ ford University Press, 1906.

Preston, Raymond. Four Ouartets Rehearsed. New York: Sheed and Ward, 1947.

Proudhon, Pierre-Joseph. De la justice dans la revolution et dans l'eralite. vol. Ti. Brussels: Office de publicite,

- Generel ldea of the Revolution in the Nineteenth Century. London: Freedon Press, TC23.

d'etat du2 decembre. Paris: Garnier, T852.

- Systeme des contradictions économiques; ou philosophiedela misere. Paris: Ernest flammarion, 1397.

- What is Property? New York: H. Fertis, 1966.

Rieff, Philip. Freud: The Mind of the Moralist. New York: Doubleday and Campany, Tnc., T96.

Robertson, Priscilla. Revolutions of 1848. New York: Harper Torchbooks, 1960.

Sartre, Jean-Paul. The Age of Reason. New York: Bantam Books, 1959.

Critique de la raison dialectique. Paris:

LibrairiegatTimard, T960.

Nausea. Hew York: New Directions, 1964.

- No Exit and Other Plays. New York: Vintage Books, $1 \overline{955}$

- The Reprieve. New York: Bantam Books, 1960. 
Sartre, Jean-Paul. Search for a Method. New York: Alfred A. Knopf, 1963 .

- Situations. Hew York: George Braziller, 1960. What is Literature? New York: Harper Colophon Books, 1965 .

- The Words. New York: George Braziller, 1964.

Seton-Hatson, Hugh. From Lenin to Khrushchev, the History of World Communism. Wew York: Frederick A. Praeger, 1960.

Stern, Fritz. The Politics of Cultural Despair. New York: Doubleday and Company, Inc., 1961.

Swart, Koenraad $U$. The Sense of vecadence in NineteenthCentury France. Martinus Nijhoff: The Hague, 1964.

Taylor, A. J. P. Eismarck - The Hancethe Statesman. New York: Vintage Books, 1967.

- A History of the First World War. New York: Befkley Publishing Corporation. 1966 .

Trilling, Lionel. Freud and the Crisis of our Culture. Boston: The Beacon Press, 1955.

Unger, Leonard. T. S. Eliot Moments and Patterns. Minneapolis: University of Minnesota Press, 1967.

Harnock, Mary. The Philosophy of Sartre. London: Hutchinson and Company, Ltd., 1265.

Weber, Carl J. (ed.). Fitzgerald's Rubaiyat. Waterville, Maine: Colby College Press, 1947.

Willey, Basil. More Nineteenth Century Studies. New York: Harper Torchbooks, 1966.

Williams, Roger L. The Vorld of Napoleon 111. New York: Collier Books, T962.

Wilson, Edmund. To the Finland Station. Garden City, New York: Anchor Books, T940.

Wohl, Robert. French Communism in the Making. Stanford, California: Stanford University Press, 1966.

Wolf, Bertram D. Marxism, One Hundred Years in the Life of a Doctrine: United States: Delta Books, 1967. 
Woodcock, George. Pierre-Joseph Proudhon. London:

Routledge \& K. Paul, 1959.

\section{Periodicals}

Allen, M. B. "Pierre-Joseph Proudhon in the Revolution of $1848, "$ Journal of Modern History, 24, (March, 1952), 1-14.

Baumer, Franklin L. "The Twentieth Century Version of the Apocalypse," Journal of liorld History, I, (January, 1954), 623-40\%

Bidou, H. "Proudhon et la guerre," Europe Nouveau, 22 , (September, 1939), 970-971.

Dillard, D. "Keynes and Proudhon," Journal of Economic History, 2, (May, 1942), 63-76.

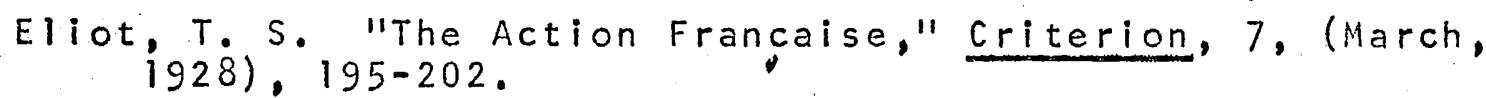

1-4. "A Commentary," The Criterion, 6, (July, 1927),

97-101. "A Commentary," The Criterion, 6, (August, 1927),

1927). 193-197.

209-292 "A Commentary," The Criterion, 6, (October, 1927),

"The Literature of Facism," Criterion, 8,

(December, 1928), 280-290.

- "Hro- Barnes and Mr. Rowse, "H Criterion, 8,

(July, 1929), 682-691.

$31-33$

"Salutation," The Criterion, 7, (January, 1928),

Freedman, Morris. "The Meaning of T. S. Eliot's Jew," South Atlantic Quarterly, 55, (April, 1956), 199-206.

Gay, Peter. "The Ascertained Past," New Pepublic, 159, (November 16, 1968), 19-22.

Guy-Grand, G. "Les Aspects de la justice selon Proudhon," Review of Philosophy, 109, (March, 1930), 286-315. 
Guy-Grand, G. "Proudhon est-il Philosophe?" Review Politique et Literature, 68, (ilay 3, 1930), 268-273.

Harrington, Michael. "Emmanuel Mounier: Tragic Optimist," The Commonweal, 60, (August 20, 1954), 439-490.

Hoffman, R. "liarx and Proudhon, A Reappraisal of their Relationship," Historian, 29, (Hay, 1967), 409-430.

Holborn, Hajo. "Hilhelm Dilthey and the Critique of Historical Reason," Journal of the History of ldeas, 11, (January, 1950), 93-118.

Howarth, Herbert. "T. S. Eliot's Criterion: The Editor and his Contributions," Comparative Literature, 11 , (spring, 1959), 97-1 10 .

Maccoby, H. Z. "Two Notes on 'Murder in the Cathedral," Notes and Queries, 14, (July, 1967), 253-256.

Martin, B. K. "Prufrock, Bleistein E Company," Notes and Queries, 14, (July, 1967), 257.

Morris, George L. K. "Marie, Marie, Hold on Tight," Partisan Review, 21, (March-April, 1954), 231-233.

Noland, A. "Pierre-Joseph Proudhon, Socialist as Social Scientist," American Journal of Economics, 26, (July,

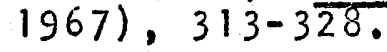

- "Proudhon and Rousseau," Journal of the History of Tdeas, 28, (January, 1967), 33-54.

Oberg. Arthur K. "The Cocktail Party and the lliusion of Autonomy," Modern Drama, 11, (September, 1968), 187-194.

Pope, John C. "Prufrock and Paslcolnikov Again: A Letter from Eliot," American Literature, 18, (January, 1947). $319-321$.

Ritter, A. "Proudton and the Prob lem of Community," Review of Politics, 29, (October, 1967), 457-477.

Schapiro, Salwyn J. "Pierre-Joseph Proudhon, Harbinger of Fascism," American Historical Review, 50, (July, 1945), $714-735$.

Schlesinger, P. "Proudhon et Sade," Mercure Francaise, 312, (June, 1951), 373.

Spangler, George M. "The Education of Henry Adams as a Source for the Lovesong of J. Alfred Prufrock," Notes and Queries, 15, (August, 1968), 295-296. 
Tucker, R. G. "The Cunning of Reason in Hegel and Marx," Review of Politics, 18, (July, 1956), 269-295. 